


\title{
Verbeteren tijdstip voorjaarsbemesting op basis van bodemtemperatuur
}

\author{
G. Holshof, I.E. Hoving
}

Wageningen Livestock Research

Dit onderzoek is uitgevoerd door Wageningen Livestock Research, in opdracht van ZuivelNL.

Wageningen Livestock Research

Wageningen, februari 2019

Rapport 1154 
Holshof, G., Hoving, I.E., 2019. Verbeteren tijdstip voorjaarsbemesting op basis van

bodemtemperatuur. Wageningen Livestock Research, Rapport 1154.

\section{Samenvatting NL}

De temperatuursom wordt als een grove maat beschouwd voor het gewenste toedieningstijdstip van stikstofkunstmest. Mogelijk dat bodemtemperatuur hiervoor een betere schatter is. Op veengrond

(KTC Zegveld) is een veldproef uitgevoerd, waarbij kunstmest al of niet in combinatie met drijfmest bij een verschillende bodemtemperatuur is toegediend. De totale periode die volgens de temperatuursom wordt aangemerkt als optimaal strooimoment bedroeg maar liefst zes weken. De strooimomenten die in deze periode lagen gaven de kleinste verschillen in grasopbrengsten en de (relatief) hoogste grasopbrengsten. De hypothese, dat rekening houden met bodemtemperatuur tot een hogere $\mathrm{N}$ benutting en daarmee drogestofopbrengst leidt, werd op basis van het onderzoek in 2018 niet bevestigd.

\section{Summary UK}

Temperature sum is considered inaccurate for the optimal application time of nitrogen fertilizer. Possibly soil temperature is a better estimate for this. On peat soil (KTC Zegveld) a field trial has been carried out, in which fertilizer was applied with or without slurry at different soil temperatures. The total period, which according to the temperature sum is regarded as optimal for spreading, was even six weeks. The spreading moments in this period gave the smallest differences in grass yield and the (relatively) highest grass yields. The hypothesis that taking into account soil temperature leads to a higher Nitrogen utilization, and therefore dry matter yield, was not confirmed by the trial in 2018.

Dit rapport is gratis te downloaden op https://doi.org/10.18174/471486 of op www.wur.nl/livestock-research (onder Wageningen Livestock Research publicaties).

\section{(C) 2019 Wageningen Livestock Research}

Postbus 338, 6700 AH Wageningen, T 03174839 53, E info.livestockresearch@wur.nl, www.wur.nl/livestock-research. Wageningen Livestock Research is onderdeel van Wageningen University \& Research.

Wageningen Livestock Research aanvaardt geen aansprakelijkheid voor eventuele schade voortvloeiend uit het gebruik van de resultaten van dit onderzoek of de toepassing van de adviezen.

Alle rechten voorbehouden. Niets uit deze uitgave mag worden vermenigvuldigd en/of openbaar gemaakt worden door middel van druk, fotokopie, microfilm of op welke wijze dan ook zonder voorafgaande toestemming van de uitgever of auteur.

Wageningen Livestock Research is NEN-EN-ISO 9001:2015 gecertificeerd.

Op al onze onderzoeksopdrachten zijn de Algemene Voorwaarden van de Animal Sciences Group van toepassing. Deze zijn gedeponeerd bij de Arrondissementsrechtbank Zwolle. 


\section{Inhoud}

Woord vooraf $\quad 5$

$\begin{array}{ll}\text { Samenvatting } & 6\end{array}$

$\begin{array}{lll}1 & \text { Inleiding } & 7\end{array}$

$2 \quad$ Materiaal en methode $\quad 8$

2.1 Bodemtemperatuur en toedieningstijdstippen $\quad 8$

2.2 Bemesting 9

2.3 Opbrengstbepaling en gewasanalyse 12

2.4 Bodemsensoren $\quad 12$

2.5 Statistische analyse $\quad 12$

2.6 Waarnemingen $\quad 12$

$\begin{array}{llr}3 & \text { Resultaten en analyse } & 13\end{array}$

3.1 Neerslag, bodemtemperatuur en strooimomenten $\quad 13$

$\begin{array}{ll}3.2 & \text { Bemestingshoeveelheden }\end{array}$

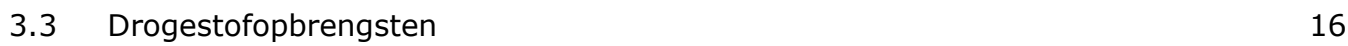

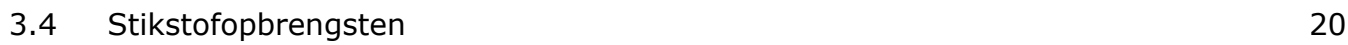

$\begin{array}{lll}3.5 & \text { Statistische analyse } & 25\end{array}$

$\begin{array}{ll}3.5 .1 & \text { Analyse droge stofopbrengst }\end{array}$

$\begin{array}{ll}3.5 .2 & \text { Analyse stikstofopbrengst } \\ 3.5 .3 & 26\end{array}$

3.5.3 Analyse Bemestingstijdstip drijfmest al dan niet in gedeelde gift. 27

4 Discussie $\quad 28$

$\begin{array}{lll}4.1 & \text { Anticiperen op bodemtemperatuur } & 28\end{array}$

$\begin{array}{lll}4.2 & \text { Opbrengsten } & 29\end{array}$

$\begin{array}{llr}5 & \text { Conclusie } & 31\end{array}$

$\begin{array}{ll}\text { Literatuur } & 32\end{array}$

$\begin{array}{lll}\text { Bijlage } 1 \quad \text { Samenvatting deskstudie } & 33\end{array}$

Bijlage 2 Ligging proefvelden $\quad 35$

Bijlage $3 \quad$ Analyse mestmonster $\quad 36$

$\begin{array}{lll}\text { Bijlage } 4 & \text { Temperatuurverloop bodem } & 37\end{array}$ 



\section{Woord vooraf}

In de praktijk wordt steeds vaker bodemtemperatuur gemeten als alternatief voor Tsom. Over de relatie tussen bodemtemperatuur, bemesting en grasgroei in het voorjaar is echter nog weinig bekend. Op melkveeproefbedrijf KTC Zegveld is een veldproef uitgevoerd om te zien of met het meten van bodemtemperatuur het voorjaarsbemestingsadvies verbeterd kan worden. Het onderzoek is gefinancierd door ZuivelNL.

Het onderzoek is uitgevoerd in samenwerking met melkveeproefbedrijf KTC Zegveld. KTC Zegveld heeft objecten aan de proef toegevoegd en de benodigde metingen op eigen kosten uitgevoerd. De proefopzet en de resultaten zijn besproken met de Commissie Bemesting Grasland en Voedergewassen (CBGV). Uitgangspunt voor de proef was dat deze eerst op één locatie uitgevoerd zou worden om te zien of sturen op bodemtemperatuur perspectief biedt. Het rapport beschrijft de resultaten van een 'proof of principle', om te zien of bodemtemperatuur tot een hogere stikstofbenutting en daarmee drogestofopbrengst leidt.

Dr. drs. I.D. de Wolf

Afdelingshoofd Veehouderij \& Omgeving, Wageningen Livestock Research 


\section{Samenvatting}

In het bemestingsadvies wordt aangegeven dat het beste tijdstip voor het bemesten van grasland in het voorjaar ligt tussen een Tsom (sommatie van alle dagtemperaturen vanaf 1 januari die boven de 0 graden Celsius liggen) van 180 en 280 graden Celsius. Deze indicatie wordt in de praktijk als vrij grof ervaren. Mogelijk bestaat een sterker verband met de bodemtemperatuur, omdat het vochtgehalte van de bodem de opwarming van de bodem beïnvloedt. In een 'proof of principle' experiment op veengrond is bij twee slootpeilen ( 20 en $55 \mathrm{~cm}$ beneden maaiveld) gekeken naar het effect van het toedienen van stikstofkunstmest bij verschillende bodemtemperaturen op de drogestof- en stikstofopbrengst. Hieruit zou een optimaal toedieningstijdstip kunnen worden afgeleid. De referentiebodemtemperatuur is gemeten op $20 \mathrm{~cm}$ beneden maaiveld. Eveneens is de bodemtemperatuur op $10 \mathrm{~cm}$ beneden maaiveld gemeten, echter op de grotere diepte treden minder grote schommelingen op en heeft daarom als referentie gediend.

Kunstmest werd gestrooid bij temperatuurklassen van 5-6, 7-8, 9-10 en 11-12 graden Celsius bodemtemperatuur, waarbij de temperatuur minimaal drie dagen moest aanhouden. Op de derde dag werd gestrooid. Voor de volgende temperatuurklasse werd minimaal vijf dagen later kunstmest gegeven. Deze behandelingen zijn uitgevoerd met- en zonder toevoegen van drijfmest (één vaste gift van $25 \mathrm{~m}^{3}$ op 27 maart), waarbij een deel van de stikstofkunstmest werd vervangen. Additioneel zijn door KTC-Zegveld bij een laag slootpeil een aantal objecten toegevoegd met een vast tijdstip van kunstmest strooien (onafhankelijk van bodemtemperatuur), namelijk op 15 februari, 22 februari, 2 maart en 9 maart. Daarnaast zijn extra drijfmestobjecten bij het lage slootpeil aangelegd, om een indicatie te krijgen voor het optimale toedieningstijdstip van drijfmest. Ook is een relatief grote gift van $50 \mathrm{~m}^{3}$ per ha gegeven, al of niet gedeeld in twee keer $25 \mathrm{~m}^{3}$ per ha, om te zien of dit een betere benutting (en dus hogere opbrengst) zou geven. De oogst van de eerste snede vond op vier verschillende momenten plaats. Daarna is een tweede snede geoogst als vervolg op het tweede en vierde oogstmoment van de eerste snede, om een verschil in eventuele nawerking te bepalen.

Tussen het tijdstip van toedienen van de kunstmest en de effectiviteit (uitgedrukt in kg drogestof en $\mathrm{kg} \mathrm{N}$ per ha) werd geen direct verband gevonden. De verschillen in drogestofopbrengst en stikstofopbrengst tussen de verschillende toedieningstijdstippen waren niet significant. Opvallend was dat de zeer vroege stikstofkunstmestgiften geen lagere opbrengsten gaven. De vroeg toegediende drijfmest gaf daarentegen een hogere opbrengst. Voor drijfmest lijken vroege giften, voor wat betreft het effect op opbrengst, de voorkeur te hebben, aangezien de relatief laat toegediende giften lagere opbrengsten gaven. Een hoge gift van $50 \mathrm{~m}^{3}$ per ha drijfmest gaf geen hogere opbrengst in de eerste snede (snede direct na toediening) en het delen van deze gift in twee keer $25 \mathrm{~m}^{3}$ per ha, had eveneens geen effect op de opbrengst.

De Tsom van 180 graden Celsius werd reeds bereikt op 12 februari, omdat januari relatief warm was, echter direct daarop viel de vorst in en bleef de Tsom meer dan drie weken ongeveer 200 graden Celsius. Het 280 graden Celsius moment werd pas bereikt op 20 maart. De totale periode, die wordt aangemerkt als optimaal strooimoment, bedroeg daarmee bijna zes weken. Binnen deze periode lagen vijf van de acht strooimomenten. Dit waren ook juist de strooimomenten met de kleinste verschillen en de (relatief) hoogste opbrengsten. De hypothese, dat rekening houden met bodemtemperatuur tot een hogere stikstofbenutting en daarmee drogestofopbrengst leidt, werd op basis van het onderzoek in 2018 niet bevestigd.

In de periode waarin de mestgiften zijn gegeven is relatief weinig neerslag gevallen en bleven de groeicondities min of meer gelijk door een trage temperatuurontwikkeling. De grasgroei kwam hierdoor moeizaam op gang, waardoor uiteindelijk geen verschillen in opbrengst ontstonden. Het is goed mogelijk dat bij een ander neerslagbeeld en een ander temperatuurverloop de resultaten wel uiteen lopen. Een herhaling van de proef is nodig om te zien in hoeverre de resultaten van 2018 zich herhalen. 


\section{$1 \quad$ Inleiding}

Het huidige bemestingsadvies (www.bemestingsadvies. $\mathrm{nl}$ ) voor gras bij toediening van de mest $(\mathrm{N})$ in het voorjaar maakt gebruik van de temperatuursom (Tsom) om het optimale tijdstip van bemesting voor $(\mathrm{N})$ kunstmest vast te stellen. De Tsom voor gras is de sommatie van alle dagtemperaturen in een kalenderjaar vanaf 1 januari hoger dan 0 graden Celsius. Gemiddeld over de jaren is de Tsom een aardige schatter voor het gewenste bemestingstijdstip van de eerste snede voor gras, maar voor individuele jaren/situaties lijkt het niet altijd even logisch om op basis van Tsom te bemesten. Afwijkende omstandigheden zijn bijvoorbeeld, wanneer de Tsom al heel vroeg bereikt wordt (eind januari) of wanneer de bodem nog te nat is om te bemesten. Ook houdt de Tsom onvoldoende rekening met verschil in grondsoorten en wordt niet voorzien in een advies voor drijfmest. Er is zodoende een behoefte aan een maat voor het optimale bemestingstijdstip die rekening houdt met verschillen tussen percelen en de weersomstandigheden. In de haalbaarheidsstudie (Gollenbeek en Hoving, 2016), die voorafgaand aan het veldonderzoek (dit rapport) is uitgevoerd, werd geconcludeerd dat over de relatie tussen bodemtemperatuur en grasgroei in het voorjaar weinig bekend is en dat het waardevol zou zijn om te zien of met het meten van bodemtemperatuur het optimale tijdstip voor voorjaarsbemesting nauwkeuriger vastgesteld kan worden. In Bijlage 1 staat de samenvatting van de betreffende studie. Met de huidige ontwikkeling van bodemtemperatuursensoren en het uitlezen van meetwaarden op afstand is het sturen van bemesting op basis van bodemtemperatuur praktisch goed uit voeren.

Het onderzoek dat in het voorliggende rapport staat beschreven had als doel om te zien of bodemtemperatuur een betere parameter is voor het bepalen van het gewenste bemestingstijdstip voor stikstofkunstmest op grasland in het vroege voorjaar dan de Tsom. Het onderzoek is gedurende één voorjaar (2018) uitgevoerd als 'proof of principle' en mogelijk als opmaat voor opschaling van het onderzoek naar meerdere jaren en meerdere grondsoorten te gebruiken. Het onderzoek zou een bijdrage kunnen leveren aan het vergroten van de mineralenefficiëntie en daarmee aan duurzaamheid en de rendabiliteit van de melkveehouderij.

Om het effect van bodemtemperatuur in combinatie met een (verschillend) tijdstip van kunstmest toedienen te toetsen, is op Kennis en Transfer Centrum (KTC) Zegveld een maaiproef uitgevoerd. In deze proef werd de bodemtemperatuur op een diepte van $10 \mathrm{~cm}$ en $20 \mathrm{~cm}$ beneden maaiveld gemeten met een temperatuursensor en via een datalogger op afstand uitgelezen. Omdat de bodemvochttoestand van grote invloed kan zijn op de bodemtemperatuurontwikkeling in de tijd is de proef aangelegd bij twee verschillende slootpeilen, namelijk een slootpeil van $25 \mathrm{~cm}$ beneden maaiveld en een slootpeil van $55 \mathrm{~cm}$ beneden maaiveld. In het vroege voorjaar is bij een hoog slootpeil, voordat gewasverdamping plaatsvindt, de bodem in principe natter dan bij een lager slootpeil.

De kunstmest is toegediend bij een uiteenlopende bodemtemperatuur, in totaal bij vier verschillende temperatuurklassen (zie volgend hoofdstuk). Additioneel heeft KTC Zegveld een aantal extra objecten toegevoegd bij het lage slootpeil, namelijk extra toedieningstijdstippen voor kunstmest, (voordat de bodemtemperatuur van 5 graden Celsius bereikt was) en extra drijfmestobjecten. In het voorliggende rapport staan de resultaten van het onderzoek en daarbij is onderscheid gemaakt tussen de objecten van de oorspronkelijke basisproef en de objecten van de additionele proef. 


\section{Materiaal en methode}

\subsection{Bodemtemperatur en toedieningstijdstippen}

Op KTC Zegveld (veengrond) is een maaiproef uitgevoerd in twee herhalingen bij zowel een hoog- als een laag slootpeil. Slootpeil en tijdstip van bemesting waren de factoren in de proef. Om te toetsen bij welke bodemtemperatuur kunstmest het meest effectief is, is gekozen om de kunstmest toe te dienen bij een reeks van verschillende bodemtemperaturen.

De proef was verdeeld in een basisdeel, waarbij bemestingen zowel bij een hoog als bij een laag slootpeil werden toegediend, en een additioneel deel waarbij alleen bij het lage slootpeil vervroegd (onafhankelijk van de bodemtemperatuur) kunstmest werd toegediend. Daarnaast werd drijfmest op extra tijdstippen en in verschillende hoeveelheden gegeven bij een hoog en laag slootpeil.

Basis

Gekozen is voor vier bodemtemperatuurklassen. Deze klassen zijn:

T1: 5-6 graden Celsius

T2: $7-8$ graden Celsius

T3: 9 -10 graden Celsius

T4: 11-12 graden Celsius

De bodemtemperatuur zal in de praktijk niet proportioneel oplopen, maar met veel variatie en daarom is gewerkt met temperatuurklassen. Als drempelwaarde werd het gemiddelde van de klassen gehanteerd.

Er werd gestrooid zodra binnen de betreffende klasse de streeftemperatuur gedurende drie opeenvolgende dagen werd gemeten. Tussen de strooimomenten van de verschillende klassen lag minimaal vijf dagen. Als referentie werd de bodemtemperatuur op een diepte van $20 \mathrm{~cm}$ onder maaiveld genomen. De keuze voor de diepte van $20 \mathrm{~cm}$ wordt verder toegelicht in de bijlage. Naast uitsluitend $\mathrm{N}$-giften met kunstmest, werden ook een aantal objecten gecombineerd met een drijfmestgift. De drijfmest werd voor alle objecten op een vast tijdstip toegediend en de kunstmest volgens in de temperatuurklassen T1 t/m T4. Als controle werd een onbemest object aangelegd. De onderzoeksobjecten van de basisproef staan in Tabel 1.

Tabel 1 Onderzoeksobjecten van de basisproef.

\begin{tabular}{|c|c|c|c|c|c|c|}
\hline \multirow[t]{2}{*}{ Mest } & Tijdstip & Restricties tijdstip & \multicolumn{4}{|c|}{ Planning } \\
\hline & & & T1 & $\mathrm{T} 2$ & T3 & T4 \\
\hline \multirow[t]{6}{*}{$\mathrm{km}$} & TO & geen kunstmest & & & & \\
\hline & T1 & na 3 dgn $5-6^{\circ} \mathrm{C}$ & & & & \\
\hline & $\mathrm{T} 2$ & na 3 dgn $7-8^{\circ} \mathrm{C}$ & & & & \\
\hline & T3 & na 3 dgn $9-10^{\circ} \mathrm{C}$ & & & & \\
\hline & T4 & na 3 dgn $10-11^{\circ} \mathrm{C}$ & & & & \\
\hline & & met minimaal 7 dgn tussenperiode & & & & \\
\hline $\mathrm{dm}$ & & eenmalig, zodra de draagkracht het toelaat & & & & \\
\hline
\end{tabular}

Additioneel

In het additionele deel zijn eveneens op vier verschillende tijdstippen bemestingen uitgevoerd, echter hier werd eerder mee gestart, zonder rekening te houden met de bodemtemperatuur. De eerste gift 
(T5) is op 15 februari toegediend, waarna nog drie giften (T6, T7 en T8) volgden met steeds een tussenperiode van één week.

Tevens werd drijfmest op drie extra tijdstippen toegediend (vroeg, midden en laat), waarbij nog twee objecten zijn toegevoegd met een gedeelde drijfmestgift (zie de volgende paragraaf voor een nadere toelichting).

\section{$2.2 \quad$ Bemesting}

In het voorjaar wordt stikstofbemesting vaak als combinatie van kunstmest en drijfmest gegeven. Daarom zijn ook objecten aangelegd waar een deel van de stikstof uit kunstmest vervangen is door stikstof uit drijfmest. Dit is uitgevoerd met een vaste giftgrootte van $25 \mathrm{~m}^{3}$ runderdrijfmest per ha, die op alle objecten op dezelfde dag gegeven is. De drijfmest werd zo vroeg mogelijk in het voorjaar toegediend op het moment dat de berijdbaarheid van de bodem dit toeliet. Dit was bij het hoge slootpeil later dan bij het lage slootpeil. Daarbij werd stikstofkunstmest op de vier bodemtemperatuur afhankelijke tijdstippen toegediend.

In het additionele deel zijn bij het lage slootpeil een aantal extra drijfmestobjecten aangelegd, om informatie te verkrijgen over het effect van optimale toedieningstijdstip van de drijfmest, de hoeveelheid drijfmest en het al dan niet delen van de eerste drijfmestgift (code $A \mathrm{t} / \mathrm{m} \mathrm{E}$ ).

In Tabel 2 staan de bemestingsobjecten weergegeven.

Tabel 2 Bemestingsobjecten, onbemest, kunstmest en drijfmest en een combinatie van drijfmest en kunstmest.

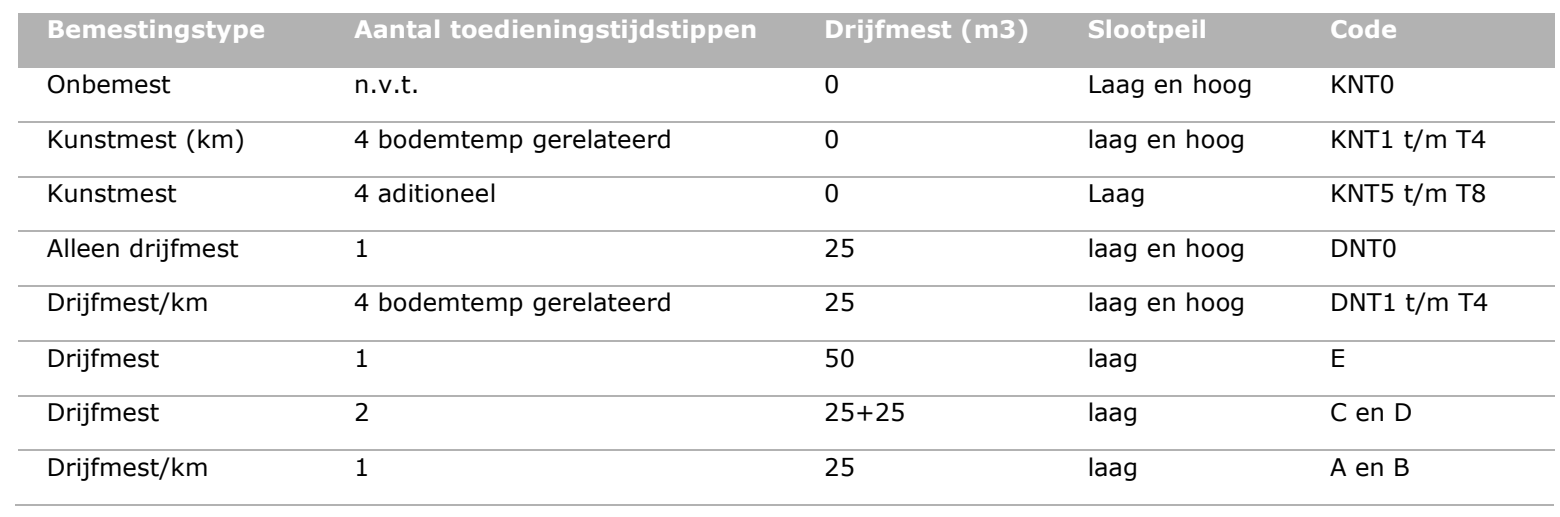

Op de extra (drijfmest)objecten ( $\mathrm{t} / \mathrm{m} \mathrm{E}$ ) was de drijfmesttoediening op verschillende momenten gepland, namelijk vroeg ( 7 maart), midden (27 maart) en laat (19 april) met een gift van $25 \mathrm{~m}^{3}$ per ha. De gift in het basisdeel werd gegeven op het middelste tijdstip ( 27 maart). Daarnaast is een dubbele gift ( $50 \mathrm{~m}^{3}$ per ha) in twee doseringen gegeven op de tijdstippen vroeg + midden en midden + laat en in één keer (gelijk met de standaard = midden). De objecten die $25 \mathrm{~m}^{3}$ per ha drijfmest kregen, hebben op 13 april 2018 een aanvullende kunstmestgift (62 kg N/ha) gehad. De standaard stikstofbemesting zonder drijfmest is ingesteld op $80 \mathrm{~kg} \mathrm{~N}$ per ha. Voor drijfmest is op basis van een stikstofgehalte van 2,2 kg/ton en een gift van $25 \mathrm{~m}^{3}$ per ha een werkzame hoeveelheid van $18 \mathrm{~kg} \mathrm{~N}$ per ha ingeschat. De aanvullende stikstofgift met KAS is zodoende op $62 \mathrm{~kg} \mathrm{~N}$ per ha gesteld. De objecten met een gedeelde of totale gift van (totaal) $50 \mathrm{~m}^{3}$ per ha drijfmest hebben geen aanvullende stikstofbemesting met kunstmest gekregen. De analyse van de gebruikte drijfmest is weergegeven in Bijlage 3.

De kunstmestobjecten zijn naast de KAS ook bemest met $50 \mathrm{~kg}$ fosfaat per ha (in de vorm van tripelsuper met $45 \%$ fosfaat) en $90 \mathrm{~kg}$ kali per ha (in de vorm van Kali-60). De drijfmestobjecten zijn (alleen) aangevuld met $20 \mathrm{~kg}$ fosfaat per ha.

Het proefveld bij het lage slootpeil is aangelegd op perceel PR04 en het proefveld bij het hoge slootpeil op perceel PR08. De ligging van de proefvelden is weergegeven op het overzichtskaartje in Bijlage 2. In het rode vlak op PR04 ligt het proefveld bij het lage slootpeil (droog) en in het blauwe vak (PR08) 
het proefveld bij het hoge slootpeil (nat). Voor de aanleg op 12 februari 2018 zijn bodemmonsters genomen (laag 0-10) om een bodemanalyse uit te voeren en de bemestingstoestand te bepalen. De uitslag van deze analyse voor perceel PR04 staat in Tabel 3. Voor veengrond wordt standaard uitgegaan van een stikstofleverend vermogen (NLV) van $250 \mathrm{~kg} \mathrm{~N}$ per ha. In de praktijk blijkt deze hoeveelheid echter behoorlijk te kunnen variëren.

De totale stikstofvoorraad was relatief hoog en de $\mathrm{C} / \mathrm{N}$ verhouding relatief laag. Het zwavelleverend vermogen (SLV) en de zwavel beschikbaarheid was goed. Het gebruik van een zwavelhoudende kunstmeststof was dus niet nodig. De fosfaatvoorziening was (te) laag, dus is extra fosfaat toegediend. De kalium, magnesium en natriumtoestand waren voldoende. De calciumtoestand was laag.

Tabel 3 Analyse bodemmonster PR04 KTC Zegveld.

\begin{tabular}{|c|c|c|c|c|}
\hline \multirow[t]{2}{*}{ Onderzoek } & $\begin{array}{l}\text { Onderzoek-/ordernr: } \\
\text { 759763/004300799 }\end{array}$ & $\begin{array}{l}\text { Datum monstername: } \\
12-02-2018\end{array}$ & \multirow[t]{2}{*}{$\begin{array}{l}\text { Datum verslag: } \\
\text { 23-02-2018 }\end{array}$} & \multirow[b]{3}{*}{ Streeftraject } \\
\hline & 4092 & & & \\
\hline Resultaat & & Eenheid & Resultaat & \\
\hline \multirow[t]{7}{*}{ Chemisch } & $\begin{array}{l}\mathrm{N} \text {-totale bodemvoorraad } \\
\mathrm{C} / \mathrm{N} \text {-ratio } \\
\mathrm{N} \text {-leverend vermogen }\end{array}$ & $\begin{array}{l}\mathrm{kg} \mathrm{N} / \mathrm{ha} \\
\mathrm{kg} \mathrm{N} / \mathrm{ha}\end{array}$ & $\begin{array}{l}14620 \\
10 \\
250\end{array}$ & $\begin{array}{l}3150-5040 \\
13-17\end{array}$ \\
\hline & $\begin{array}{l}\text { S-plantbeschikbaar } \\
\text { S-totale bodemvoorraad } \\
\text { C/S-ratio } \\
\text { S-leverend vermogen }\end{array}$ & $\begin{array}{l}\mathrm{kg} \mathrm{S/ha} \\
\mathrm{kg} \mathrm{S} / \mathrm{ha} \\
\mathrm{kg} \mathrm{S/ha}\end{array}$ & $\begin{array}{l}27 \\
4280 \\
35 \\
45\end{array}$ & $\begin{array}{l}20-30 \\
975-1860 \\
50-75 \\
20-30\end{array}$ \\
\hline & $\begin{array}{l}\text { P-plantbeschikbaar } \\
\text { P-bodemvoorraad }\end{array}$ & $\begin{array}{l}\mathrm{kg} \mathrm{P} / \mathrm{ha} \\
\mathrm{kg} \mathrm{P} / \mathrm{ha}\end{array}$ & $\begin{array}{l}0,6 \\
65\end{array}$ & $\begin{array}{l}1,4-2,0 \\
70-95\end{array}$ \\
\hline & $\begin{array}{l}\text { K-plantbeschikbaar } \\
\text { K-bodemvoorraad }\end{array}$ & $\begin{array}{l}\mathrm{kg} \mathrm{K} / \mathrm{ha} \\
\mathrm{kg} \mathrm{K} / \mathrm{ha}\end{array}$ & $\begin{array}{l}190 \\
380\end{array}$ & $\begin{array}{l}35-55 \\
255-310\end{array}$ \\
\hline & $\begin{array}{l}\text { Ca-plantbeschikbaar } \\
\text { Ca-bodemvoorraad }\end{array}$ & $\begin{array}{l}\mathrm{kg} \mathrm{Ca} / \mathrm{ha} \\
\mathrm{kg} \mathrm{Ca} / \mathrm{ha}\end{array}$ & $\begin{array}{l}5 \\
5265\end{array}$ & $\begin{array}{l}45-105 \\
7455-11185\end{array}$ \\
\hline & $\begin{array}{l}\text { Mg-plantbeschikbaar } \\
\text { Mg-bodemvoorraad }\end{array}$ & $\begin{array}{l}\mathrm{kg} \mathrm{Mg} / \mathrm{ha} \\
\mathrm{kg} \mathrm{Mg} / \mathrm{ha}\end{array}$ & $\begin{array}{l}420 \\
840\end{array}$ & $\begin{array}{l}225-270 \\
215-315\end{array}$ \\
\hline & $\begin{array}{l}\text { Na-plantbeschikbaar } \\
\text { Na-bodemvoorraad }\end{array}$ & $\begin{array}{l}\mathrm{kg} \mathrm{Na} / \mathrm{ha} \\
\mathrm{kg} \mathrm{Na} / \mathrm{ha}\end{array}$ & $\begin{array}{l}70 \\
105\end{array}$ & $\begin{array}{l}65-100 \\
15-20\end{array}$ \\
\hline \multirow{5}{*}{ Fysisch } & Zuurgraad (pH) & & 5,1 & $5,0-5,6$ \\
\hline & Organische stof & $\%$ & 48,2 & \\
\hline & Koolzure kalk & $\%$ & 1,3 & $2,0-3,0$ \\
\hline & $\begin{array}{l}\text { Klei }(<2 \mu \mathrm{m}) \\
\text { Silt }(2-50 \mu \mathrm{m}) \\
\text { Zand }(>50 \mu \mathrm{m}) \\
\text { Slib }(<16 \mu \mathrm{m})\end{array}$ & $\begin{array}{l}\% \\
\% \\
\% \\
\%\end{array}$ & $\begin{array}{l}28 \\
19 \\
4 \\
34\end{array}$ & \\
\hline & $\begin{array}{l}\text { Klei-humus (CEC) } \\
\text { CEC-bezetting } \\
\text { Ca-bezetting } \\
\text { Mg-bezetting } \\
\text { K-bezetting } \\
\text { Na-bezetting } \\
\text { H-bezetting } \\
\text { Al-bezetting }\end{array}$ & $\begin{array}{l}\mathrm{mmol}+/ \mathrm{kg} \\
\% \\
\% \\
\% \\
\% \\
\% \\
\% \\
\%\end{array}$ & $\begin{array}{l}613 \\
90 \\
68 \\
18 \\
2,5 \\
1,2 \\
<0,1 \\
<0,1\end{array}$ & $\begin{array}{l}>472 \\
>95 \\
75-85 \\
6,0-10 \\
2,0-5,0 \\
1,0-1,5 \\
<1,0 \\
<1,0\end{array}$ \\
\hline
\end{tabular}


De analyseresultaten van perceel PR08 staan in Tabel 4. Ook op dit perceel was de N-totaal bodemvoorraad relatief hoog en de $\mathrm{C} / \mathrm{N}$ ratio relatief laag. De zwaveltoestand was voldoende, waardoor geen zwavelhoudende meststof nodig was. Op PR08 was weliswaar iets meer fosfor beschikbaar dan op PR08, maar ook op dit perceel is een aanvullende fosfaatbemesting toegediend. De overige elementen waren voldoende beschikbaar.

Tabel 4 Analyse bodemmonster PR08 KTC Zegveld.

\begin{tabular}{|c|c|c|c|c|}
\hline \multirow[t]{2}{*}{ Onderzoek } & $\begin{array}{l}\text { Onderzoek-/ordernr: } \\
759760 / 004300799\end{array}$ & $\begin{array}{l}\text { Datum monstername: } \\
12-02-2018\end{array}$ & \multirow[t]{2}{*}{$\begin{array}{l}\text { Datum verslag: } \\
22-02-2018\end{array}$} & \multirow[b]{3}{*}{ Streeftraject } \\
\hline & 4092 & & & \\
\hline Resultaat & & Eenheid & Resultaat & \\
\hline \multirow[t]{7}{*}{ Chemisch } & $\begin{array}{l}\mathrm{N} \text {-totale bodemvoorraad } \\
\mathrm{C} / \mathrm{N} \text {-ratio } \\
\mathrm{N} \text {-leverend vermogen }\end{array}$ & $\begin{array}{l}\mathrm{kg} \mathrm{N} / \mathrm{ha} \\
\mathrm{kg} \mathrm{N} / \mathrm{ha}\end{array}$ & $\begin{array}{l}13750 \\
10 \\
250\end{array}$ & $\begin{array}{l}3740-5990 \\
13-17\end{array}$ \\
\hline & $\begin{array}{l}\text { S-plantbeschikbaar } \\
\text { S-totale bodemvoorraad } \\
\text { C/S-ratio } \\
\text { S-leverend vermogen }\end{array}$ & $\begin{array}{l}\mathrm{kg} \mathrm{S} / \mathrm{ha} \\
\mathrm{kg} \mathrm{S} / \mathrm{ha} \\
\mathrm{kg} \mathrm{S} / \mathrm{ha}\end{array}$ & $\begin{array}{l}30 \\
3285 \\
43 \\
45\end{array}$ & $\begin{array}{l}20-30 \\
1160-2205 \\
50-75 \\
20-30\end{array}$ \\
\hline & $\begin{array}{l}\text { P-plantbeschikbaar } \\
\text { P-bodemvoorraad }\end{array}$ & $\begin{array}{l}\mathrm{kg} \mathrm{P} / \mathrm{ha} \\
\mathrm{kg} \mathrm{P} / \mathrm{ha}\end{array}$ & $\begin{array}{l}1,2 \\
130\end{array}$ & $\begin{array}{l}1,6-2,4 \\
80-115\end{array}$ \\
\hline & $\begin{array}{l}\text { K-plantbeschikbaar } \\
\text { K-bodemvoorraad }\end{array}$ & $\begin{array}{l}\mathrm{kg} \mathrm{K} / \mathrm{ha} \\
\mathrm{kg} \mathrm{K} / \mathrm{ha}\end{array}$ & $\begin{array}{l}190 \\
375\end{array}$ & $\begin{array}{l}45-65 \\
235-295\end{array}$ \\
\hline & $\begin{array}{l}\text { Ca-plantbeschikbaar } \\
\text { Ca-bodemvoorraad }\end{array}$ & $\begin{array}{l}\mathrm{kg} \mathrm{Ca} / \mathrm{ha} \\
\mathrm{kg} \mathrm{Ca} / \mathrm{ha}\end{array}$ & $\begin{array}{l}50 \\
4500\end{array}$ & $\begin{array}{l}55-125 \\
5645-8465\end{array}$ \\
\hline & $\begin{array}{l}\text { Mg-plantbeschikbaar } \\
\text { Mg-bodemvoorraad }\end{array}$ & $\begin{array}{l}\mathrm{kg} \mathrm{Mg} / \mathrm{ha} \\
\mathrm{kg} \mathrm{Mg} / \mathrm{ha}\end{array}$ & $\begin{array}{l}460 \\
995\end{array}$ & $\begin{array}{l}270-320 \\
195-300\end{array}$ \\
\hline & $\begin{array}{l}\text { Na-plantbeschikbaar } \\
\text { Na-bodemvoorraad }\end{array}$ & $\begin{array}{l}\mathrm{kg} \mathrm{Na} / \mathrm{ha} \\
\mathrm{kg} \mathrm{Na} / \mathrm{ha}\end{array}$ & $\begin{array}{l}75 \\
105\end{array}$ & $\begin{array}{l}75-120 \\
15-25\end{array}$ \\
\hline \multirow{5}{*}{ Fysisch } & Zuurgraad $(\mathrm{pH})$ & & 5,2 & $5,0-5,6$ \\
\hline & $\begin{array}{l}\text { C-organisch } \\
\text { Organische stof } \\
\text { C/OS-ratio }\end{array}$ & $\begin{array}{l}\% \\
\%\end{array}$ & $\begin{array}{l}18,9 \\
39,5 \\
0,48\end{array}$ & $0,45-0,55$ \\
\hline & Koolzure kalk & $\%$ & 1,0 & $2,0-3,0$ \\
\hline & $\begin{array}{l}\text { Klei }(<2 \mu \mathrm{m}) \\
\text { Silt }(2-50 \mu \mathrm{m}) \\
\text { Zand }(>50 \mu \mathrm{m}) \\
\text { Slib }(<16 \mu \mathrm{m})\end{array}$ & $\begin{array}{l}\% \\
\% \\
\% \\
\%\end{array}$ & $\begin{array}{l}28 \\
21 \\
11 \\
34\end{array}$ & \\
\hline & $\begin{array}{l}\text { Klei-humus (CEC) } \\
\text { CEC-bezetting } \\
\text { Ca-bezetting } \\
\text { Mg-bezetting } \\
\text { K-bezetting } \\
\text { Na-bezetting } \\
\text { H-bezetting } \\
\text { Al-bezetting }\end{array}$ & $\begin{array}{l}\mathrm{mmol}+/ \mathrm{kg} \\
\% \\
\% \\
\% \\
\% \\
\% \\
\% \\
\%\end{array}$ & $\begin{array}{l}464 \\
93 \\
65 \\
24 \\
2,8 \\
1,3 \\
<0,1 \\
<0,1\end{array}$ & $\begin{array}{l}>411 \\
>95 \\
75-85 \\
6,0-10 \\
2,0-5,0 \\
1,0-1,5 \\
<1,0 \\
<1,0\end{array}$ \\
\hline
\end{tabular}




\subsection{Opbrengstbepaling en gewasanalyse}

Aangezien een snede bij diverse geplande opbrengsten geoogst of geweid kan worden is gekozen om de eerste snede op vier tijdstippen (groeiverloop) te oogsten: T1 t/m T4. Het gevolgde oogstpatroon geeft zodoende inzicht in het verloop van de stikstofopname en de drogestofproductie. Bovendien werd met de meerdere oogsttijdstippen voorkomen dat bij het laatste bemestingstijdstip de stikstofopname te zeer door een korte groeiduur zou worden beperkt. Ook is gekeken of deze stikstof eventueel in een vervolgsnede (alsnog) beschikbaar zou komen, omdat mogelijk een verschil in stikstofopname ontstaat bij een verschillend tijdstip van bemesting. Van de objecten T2 en T4 van de eerste snede is daarom ook de tweede snede geoogst. Deze tweede snede is niet bemest.

De proefvelden zijn geoogst met de Haldrup proefveldmaaier met een werkbreedte van $150 \mathrm{~cm}$. Op elk object is bij oogst een baan van ongeveer 6-7 meter lengte uitgemaaid, de netto strook. Van deze baan is het versgewicht bepaald en een monster gestoken van ongeveer 500 gram versgewicht om het drogestofgehalte te bepalen (24 uur gedroogd bij 70 graden Celsius). Na drogen is het grasmonster geanalyseerd (Eurofins) op het $\mathrm{N}$-totaalgehalte via de NIRS methode. Aan de hand van het geanalyseerde $\mathrm{N}$-totaalgehalte is de stikstofopbrengst berekend.

\section{$2.4 \quad$ Bodemsensoren}

Het tijdstip van de bemesting is afhankelijk gesteld van de bodemtemperatuur. Om zicht te krijgen op de bodemtemperatuur is per proefveld (PR04 en PR08) een bodemsensor geplaatst, waarmee de bodemtemperatuur op 10 en $20 \mathrm{~cm}$ onder maaiveld in tweevoud werd gemeten. Op dezelfde locaties werd de grondwaterstand met een druksensor in een peilbuis continue gemeten. De sensoren zijn op 7 februari 2018 geplaatst en na de oogst van de tweede snede op 6 juni 2018 weer verwijderd.

\subsection{Statistische analyse}

Gekeken is naar het hoofdeffect van het tijdstip van toediening van de kunstmest op zowel de drogestofopbrengst als de stikstofopbrengst. Getoetst is of het tijdstip van oogst interacteerde met het tijdstip van bemesten. Daarnaast is ook gekeken of interactie plaatsvond tussen het tijdstip van bemesten en de combinatie met het gebruik van drijfmest (waarbij een deel van de stikstof uit kunstmest vervangen is door stikstof uit drijfmest). Voor deze analyse zijn de objecten KNT1 t/m KNT4 gebruikt die op beide percelen (hoog en laag peil) hebben gelegen, als ook de objecten DNT1 $\mathrm{t} / \mathrm{m}$ DNT4. Bij het lage slootpeil (perceel PR04) waren extra tijdstippen van kunstmest toediening toegevoegd (KNT5 t/m KNT8). Daarnaast is ook gekeken naar een interactie-effect met slootpeil. Als referentieobject zijn de objecten zonder kunstmest (KNTO en DNT0) gebruikt.

De analyse is uitgevoerd met het statistische pakket Genstat (18th) en daarbij is gebruik gemaakt van REML, vanwege een ongebalanceerde dataset. Op het perceel met het lage slootpeil lagen meer objecten dan op het perceel met het hoge slootpeil en het maaischema was niet voor alle objecten gelijk.

De objecten A t/m E (additionele proef), met de gedeelde drijfmestgiften en de verschillende toedieningstijdstippen zijn apart geanalyseerd. Deze set was wel gebalanceerd en kon worden geanalyseerd met ANOVA. Van de objecten geoogst op oogsttijdstip 2 en 4 is een tweede snede geoogst (onbemest) om de nawerking te bepalen. De analyse heeft plaatsgevonden op de totale opbrengst van snede 1 en snede 2 en is ook met ANOVA uitgevoerd.

\subsection{Waarnemingen}

In de proef zijn de volgende waarnemingen gedaan:

- Bodemtemperatuur op 10 en $20 \mathrm{~cm}$ beneden maaiveld, continu

- Grondwaterstand, continue

- Grasopbrengst in de eerste snede op vier tijdstippen

- Grasopbrengst in de tweede snede (volgend op tijdstip 2 en 4 uit de eerste snede) op één tijdstip

- $\quad$ Gewasanalyses (N-totaal bepaling via NIRS)

- Bodemvruchtbaarheidsanalyse per perceel/slootpeil. 


\section{Resultaten en analyse}

\subsection{Neerslag, bodemtemperatuur en strooimomenten}

Het effect van stikstofbemesting is mede afhankelijk vochtvoorziening en daarmee van de hoeveelheid neerslag. De neerslag van 1 januari t/m 20 juni 2018 van het KNMI neerslagstation Zegveld staat in Figuur 1.
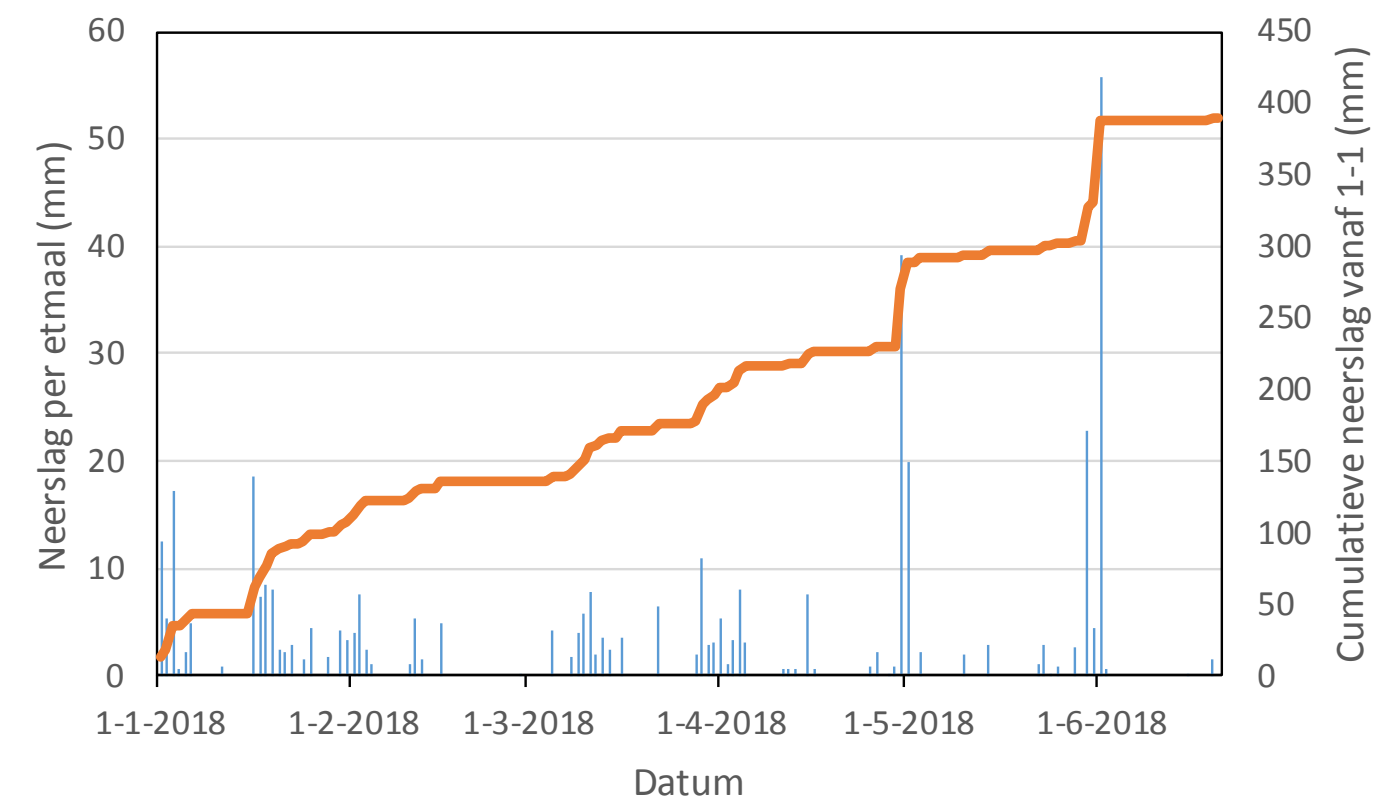

Figuur 1 Cumulatieve neerslag van1 januari tot en met 20 juni 2018 KNMI-neerslagstation Zegveld.

Voor aanvang van de proef is in januari en februari 2018 ongeveer $140 \mathrm{~mm}$ neerslag gevallen. Vanaf half februari was sprake van een droge(re) periode. Half maart heeft het op een aantal dagen geregend, waardoor de gestrooide kunstmest makkelijk kon oplossen. April was een relatief droge maand, maar leverde op de relatief natte veengrond geen problemen op met droogte. Begin mei is de bodemvochtvoorraad aangevuld met twee grote neerslaghoeveelheden van respectievelijk 40 en 20 $\mathrm{mm}$. Droogte was niet aan de orde bij de groei van de eerste en tweede snede. Wel had de regen invloed op de draagkracht bij met name het hoge slootpeil. Hierdoor werd de drijfmest relatief laat toegediend op 19 april.

De bodemtemperatuur voor perceel PR04 (laag slootpeil) is voor de twee dieptes beneden maaiveld als gemiddelde en van twee sensoren per etmaal weergegeven in figuur 2 voor de periode van 7 februari tot 6 juni 2018. In de bijlage is de figuur voor het hoge slootpeil weergegeven. In figuur 2 is tevens de buitenluchttemperatuur (gemiddelde etmaaltemperatuur van KNMI station De Bilt) weergegeven. Een voorlopige vuistregel vanuit de praktijk is dat de groei begint bij een bodemtemperatuur van 8 graden Celsius. Daarom is deze 8 -gradenlijn eveneens in de figuur weergegeven. 


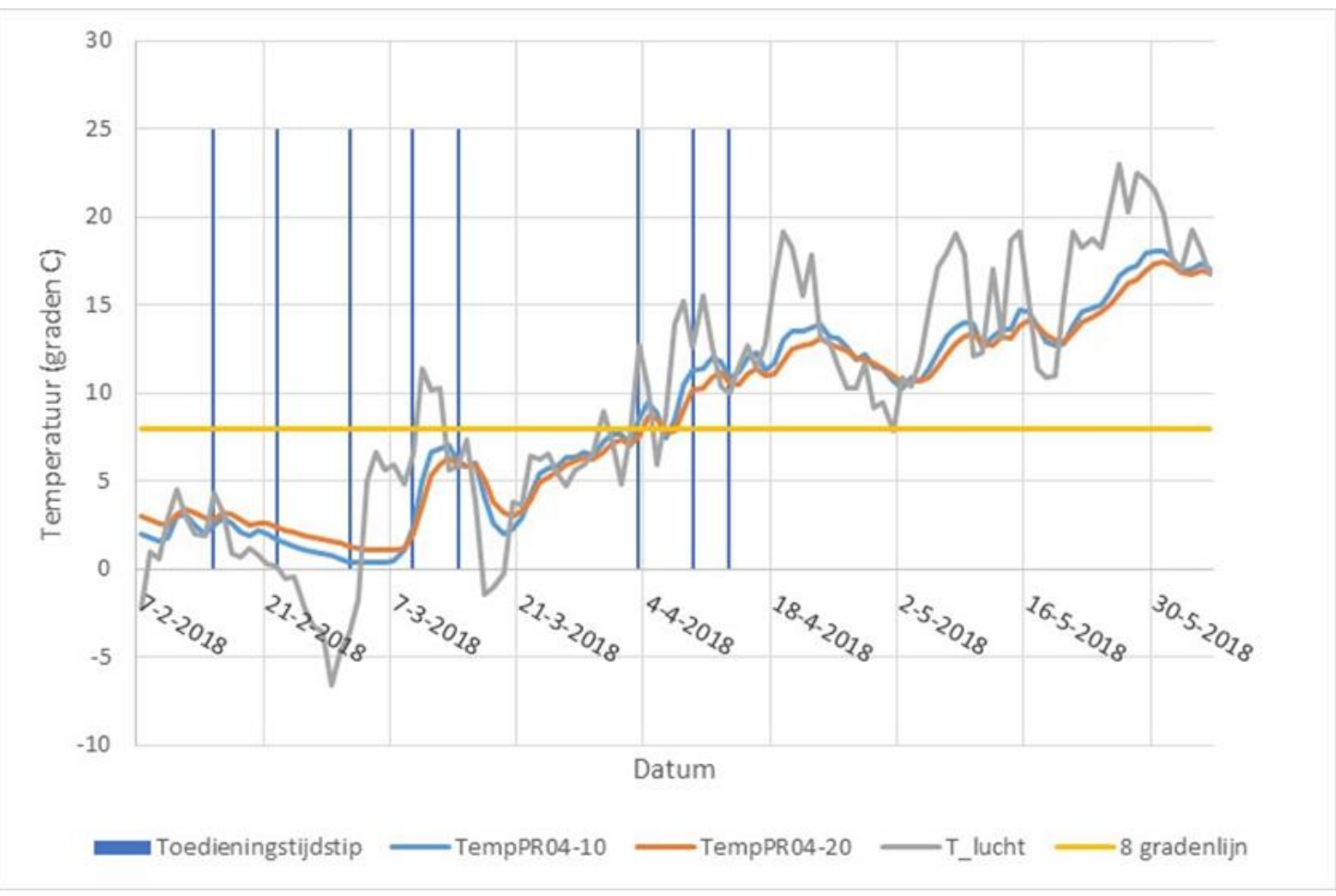

Figuur 2 Bodemtemperatuur op 10 en $20 \mathrm{~cm}$ beneden maaiveld en de luchttemperatuur in het voorjaar van 2018 bij een laag slootpeil op veengrond. De verticale kolommen betreft de toedieningstijdstippen voor kunstmest.

Het vroege voorjaar startte met een koude periode, waarbij de laagste temperaturen eind februaribegin maart werden gehaald. Op 4 maart leek een einde aan de winterperiode te komen met snel oplopende temperaturen. Na half maart ging de temperatuur echter weer snel naar beneden. Daarna volgden geen koude perioden meer en steeg de temperatuur.

Relatief vroeg in het jaar zijn als eerste de vier additionele kunstmest objecten gestrooid, namelijk op 15 februari, 22 februari, 2 maart en 9 maart (linker vier verticale balken in figuur 2). Op 11 maart kwam de temperatuur voor het eerst boven de 5 graden Celsius en bleef daar ook een volledige week boven. Op 14 maart werd de eerste kunstmest van de basisproef met klassen voor bodemtemperatuur gestrooid. Daarna kwam een koude periode. Op 31 maart kwam de bodemtemperatuur voor pas boven de 7 graden Celsius (ondertemperatuur tweede temperatuurklasse) en pas op 3 april werd voor het tweede temperatuurtijdstip bemest. Door een kleine temperatuurterugval op 5 april (gemiddelde luchttemperatuur 5.9 graden Celsius) stagneerde de opwarming van de bodem. Op 8 april kwam de bodemtemperatuur boven de 9 graden Celsius. De vooruitzichten ten aanzien van de temperatuur waren op dat moment erg goed. Er werd een snelle stijging verwacht. Daarom is op 9 april voor het derde tijdstip gestrooid. De laatste klasse (10-11 graden Celsius) vertoonde veel overlap met de klasse 9-10 graden Celsius. Om enig relevant verschil te houden is de laatste klasse op 13 april gestrooid, waarbij achteraf gezien de strooidatum voor de derde klasse goed is gekozen, omdat bij een strikte naleving van de opzet de kunstmest op twee opeenvolgende dagen gestrooid had moeten worden.

Een natte(re) bodem warmt in theorie langzamer op. Naar verwachting stijgt de bodemtemperatuur bij een hoog slootpeil zodoende langzamer dan bij een laag slootpeil. Ter vergelijk is in Figuur 3 het bodemtemperatuurverloop gemeten op een diepte van $20 \mathrm{~cm}$ beneden maaiveld van op de percelen die het lage en hoge slootpeil) vertegenwoordigen tegen elkaar uitgezet. 


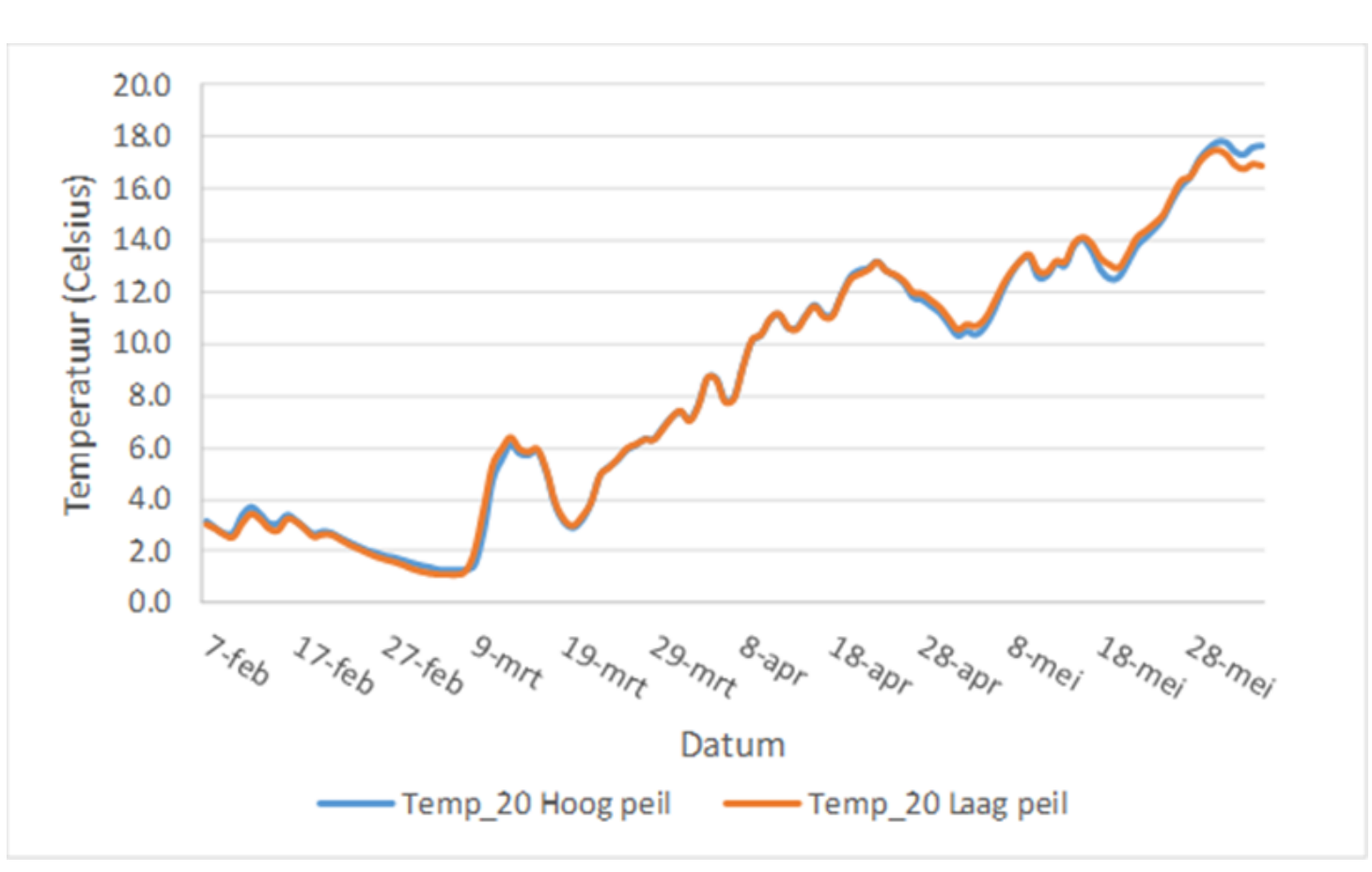

Figuur 3 Bodemtemperatuurverloop (20 cm-mv) bij een hoog en laag slootpeil op veengrond in 2018.

Uit figuur 3 blijkt dat geen verschil in opwarming is geweest tussen hoog en laag slootpeil. De kunstmest is daarom op beide percelen steeds gelijktijdig gestrooid. Wel werd duidelijk verschil in draagkracht (fysiek vastgesteld, niet gemeten) waargenomen. De drijfmest (standaard gift) werd zodoende op verschillende tijdstippen toegediend, namelijk bij een laag slootpeil op 27 maart en bij een hoog slootpeil veel later op 19 april.

\subsection{Bemestingshoeveelheden}

In deze paragraaf wordt een kort overzicht gegeven van de bemestingshoeveelheden die werkelijk toegediend zijn en (nogmaals) de tijdstippen. De 'basis' drijfmestgift bij het lage slootpeil (PR04) was $27,3 \mathrm{~m}^{3}$ die op 27 maart is toegediend. Op 19 april is $26,5 \mathrm{~m}^{3}$ toegediend op de drijfmestobjecten bij hoog slootpeil (op PR08). De toedieningstijdstippen en de gegeven hoeveelheid van deze additionele drijfmestobjecten zijn weergegeven in Tabel 5.

Tabel 5 Toedieningstijdstippen en hoeveelheden van de additionele drijfmestobjecten.

\begin{tabular}{llll} 
Code & Omschrijving & Datum gift & Gift $\left(\mathrm{m}^{3}\right)$ \\
A & 25Vroeg & 7 maart & 25,6 \\
\hline B & 25Laat & 19 april & 26,5 \\
\hline C & 25Vroeg+25Laat & 7 maart +19 april & $25,6+26,5$ \\
\hline D & 25Midden+25Laat & 27 maart +19 april & $27,3+26,5$ \\
\hline E & 50Midden & 27 maart & 54,4 \\
\hline
\end{tabular}

In Tabel 6 staan de hoeveelheden kunstmest en de toedieningsdata voor stikstof. De aanvullende fosfaat en kali is op 30 maart gegeven. 


\begin{tabular}{|c|c|c|c|c|}
\hline Object & Datum gift & $\mathrm{Kg} / \mathrm{ha} \mathrm{N}$ & $\mathrm{Kg} / \mathrm{ha} \mathrm{P}_{2} \mathrm{O}_{5}$ & $\mathrm{Kg} / \mathrm{ha} \mathrm{K}_{2} \mathrm{O}$ \\
\hline Controle & - & 0 & 50 & 90 \\
\hline KN T1 & 14 maart & 80 & 50 & 90 \\
\hline KN T2 & 3 april & 80 & 50 & 90 \\
\hline KN T3 & 9 april & 80 & 50 & 90 \\
\hline \multicolumn{5}{|c|}{ Additionele objecten toegevoegd aan de basisproef door KTC Zegveld (alleen bij laag slootpeil) } \\
\hline KN T5 (additioneel) & 15 februari & 80 & 50 & 90 \\
\hline KN T6 (additioneel) & 22 februari & 80 & 50 & 90 \\
\hline KN T7 (additioneel) & 2 maart & 80 & 50 & 90 \\
\hline
\end{tabular}

\subsection{Drogestofopbrengsten}

\section{Kunstmestobjecten}

In Figuur 4 is de gemiddelde drogestofopbrengst weergegeven per toedieningstijdstip van de kunstmest en per maaimoment. Dit is het gemiddelde van de twee percelen (dus gemiddeld over hoog en laag slootpeil), de kunstmest (KN T1 t/m KN T4) objecten en de twee herhalingen. Deze figuur geeft een eerste indruk (nog geen statistische analyse) van het effect van het bemestingstijdstip op de drogestofopbrengst van de eerste snede en de ontwikkeling van deze hoeveelheid in de tijd (los van het slootpeil; deze vergelijking wordt later gemaakt). De bemestingstijdstippen zijn weergegeven in de legenda. Het controle-object is niet bemest. De bemestingsdata voor de kunstmest uit de basisproef waren 14 maart, 3 april, 9 april en 13 april (voor beide slootpeilen). De bemestingsdata voor de additionele objecten waren 15 februari, 22 februari, 2 maart en 9 maart.

De eerste snede is op vier tijdstippen geoogst: bij een laag slootpeil op 20 april, 25 april, 4 mei en 15 mei en bij een hoog slootpeil op 26 april, 4 mei, 11 mei en 15 mei. Het maaitijdstip is genummerd, omdat in de figuur een gemiddelde weergegeven is. MT1 is dus het gemiddelde van de opbrengst op maaitijdstip 20 april bij laag slootpeil en 26 april bij hoog slootpeil.

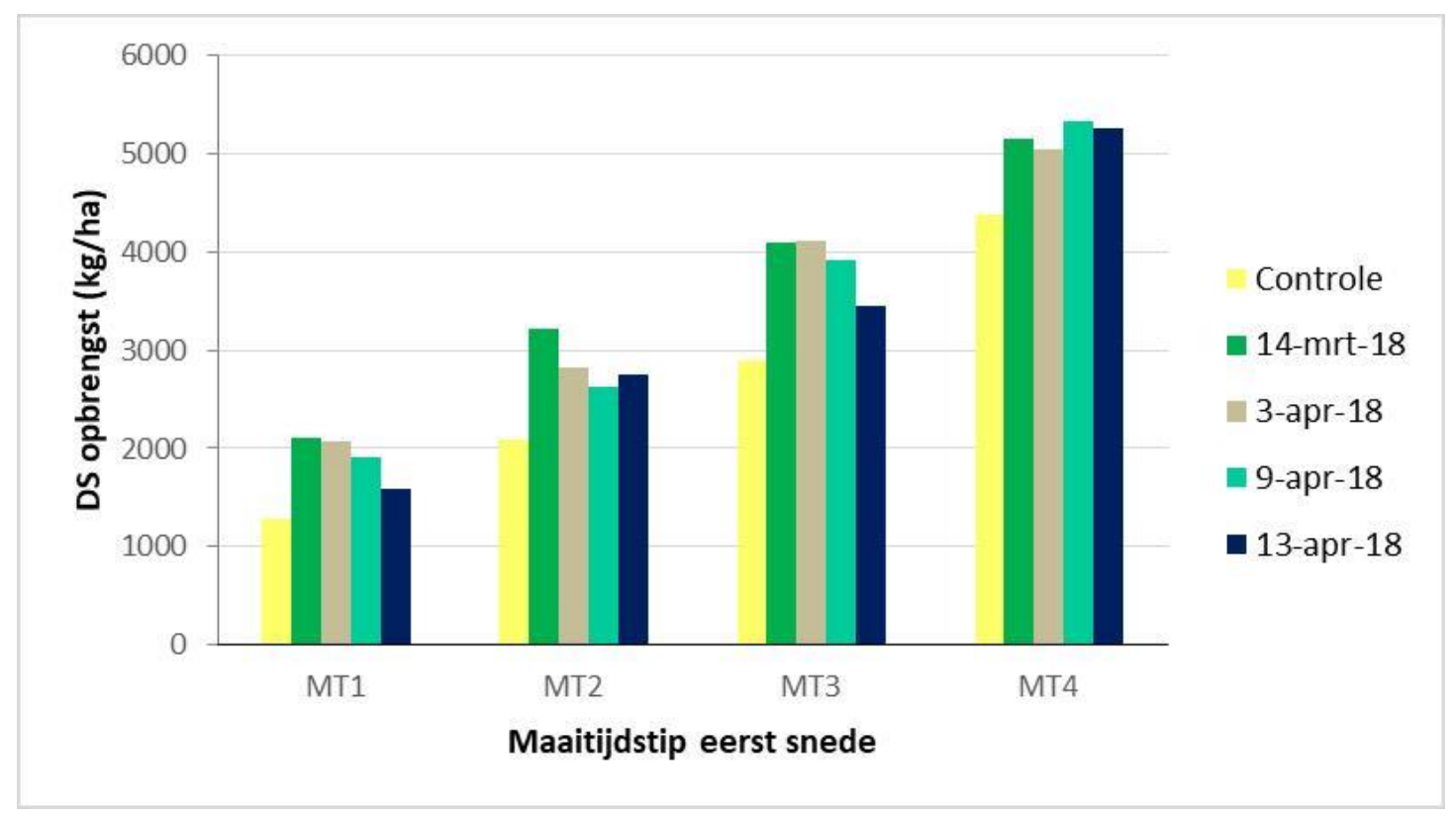

Figuur 4 Grasopbrengsten eerste snede op veen in 2018 bij vier verschillende tijdstippen van toediening van kunstmest op vier maaitijdstippen gemiddeld bij twee slootpeilen. 
De onbemeste velden (referentie) hebben op alle oogsttijdstippen de laagste opbrengst, maar geven ook goed weer op welk moment het stikstofeffect van kunstmest het grootst was (verschil bemeste velden en het onbemeste object). Het eerste maaitijdstip was op 20 april (laag slootpeil) en op 26 april (hoog slootpeil). Dit was één week respectievelijk bijna twee weken na de laatste stikstofgift (13 april). Vooral op dit eerste maaitijdstip blijft de opbrengst van de op 13 april bemeste objecten achter bij de andere bemestingstijdstippen. Dit kan er op wijzen dat de tijd tussen bemesting en oogst te kort is geweest om de toegediende $\mathrm{N}$ ook daadwerkelijk om te zetten in drogestof. Op het tweede maaitijdstip waren de verschillen tussen toedieningstijdstip 2, 3 en 4 nagenoeg verdwenen. Vanaf dat moment is er geen duidelijk beeld meer in de relatie toedieningstijdstip en opbrengst.

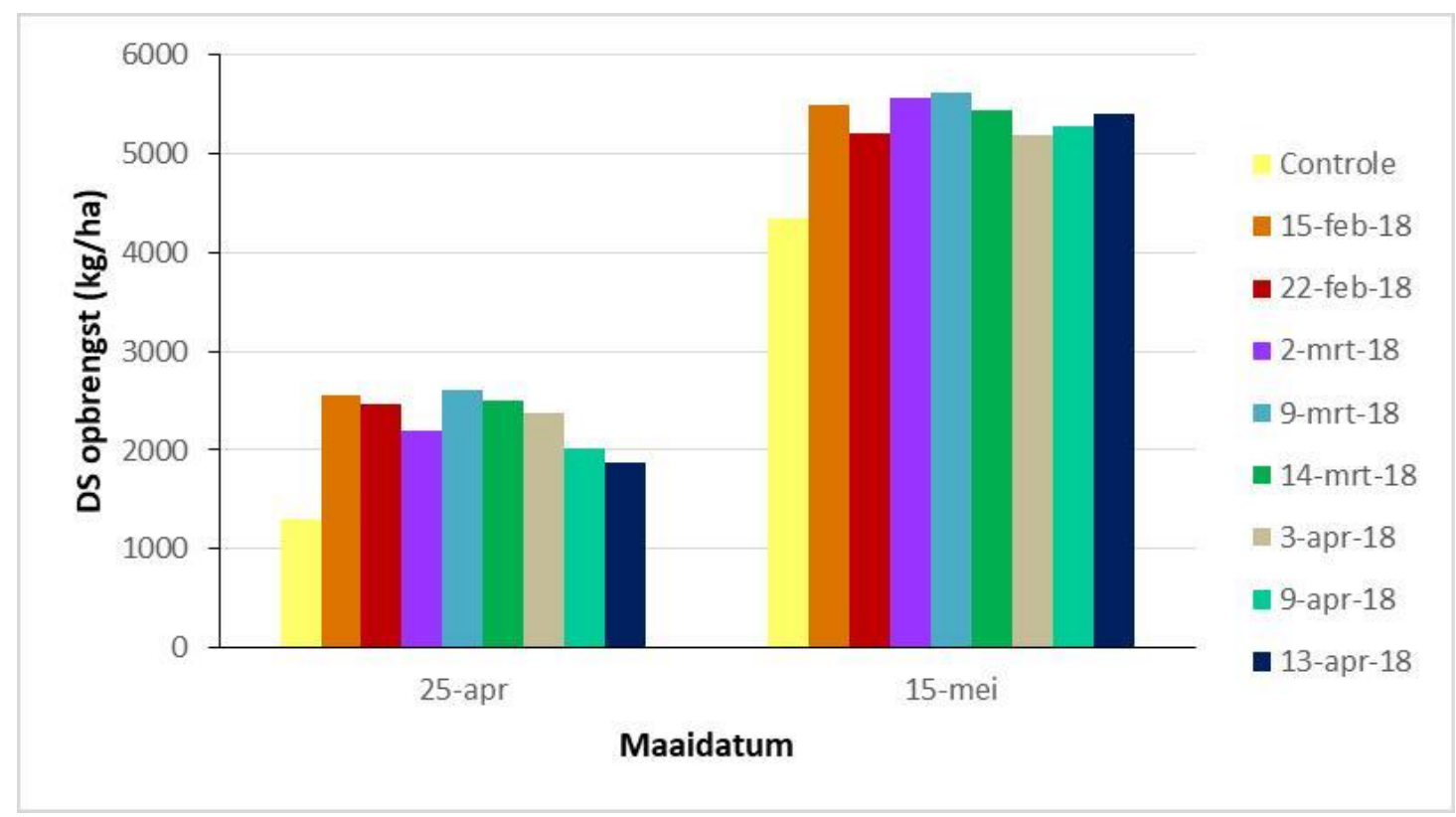

Figur $5 \quad$ Relatie tijdstip bemesten en droge stofopbrengst bij maaien op 2 tijdstippen bij een laag slootpeil op veen.

In Figuur 5 zijn de droge stofopbrengsten van alle kunstmestobjecten bij een laag slootpeil (PR04) weergegeven bij oogst op T2 (25 april) en T4 (15 mei ). NB: KN T5 t/m KN T8 zijn alleen aangelegd bij een laag slootpeil, zonder een combinatie met drijfmest en alleen op tijdstip T2 en T4 geoogst. Er werd geen duidelijk relatie gevonden tussen het tijdstip van bemesten en de gevonden opbrengsten. Op 25 april lijken de later bemeste objecten een lagere opbrengst te geven, terwijl dat beeld op 15 mei niet meer zo duidelijk is. Daarbij is het effect van tijdstip bemesten op de opbrengst niet consistent. Wel is de opbrengst van alle bemeste objecten hoger dan het onbemeste (controle) object. De statistische analyse wijst uit in hoeverre sprake is van een significant effect en vervolgens of dit relevant c.q. bruikbaar is voor de praktijk (zie paragraaf 3.5 ).

Omdat mogelijk nog nawerking optreedt van $\mathrm{N}$ dat niet volledig is benut in de eerste snede is van de objecten die op T2 (25 april) en T4 (15 mei) gemaaid zijn, nog een tweede snede gemaaid op 5 juni. De cumulatieve opbrengst van beide sneden staat in Figuur 6. Gekozen is voor de situatie bij het lage slootpeil, omdat daar een brede range aan toedieningstijdstippen is toegepast. 


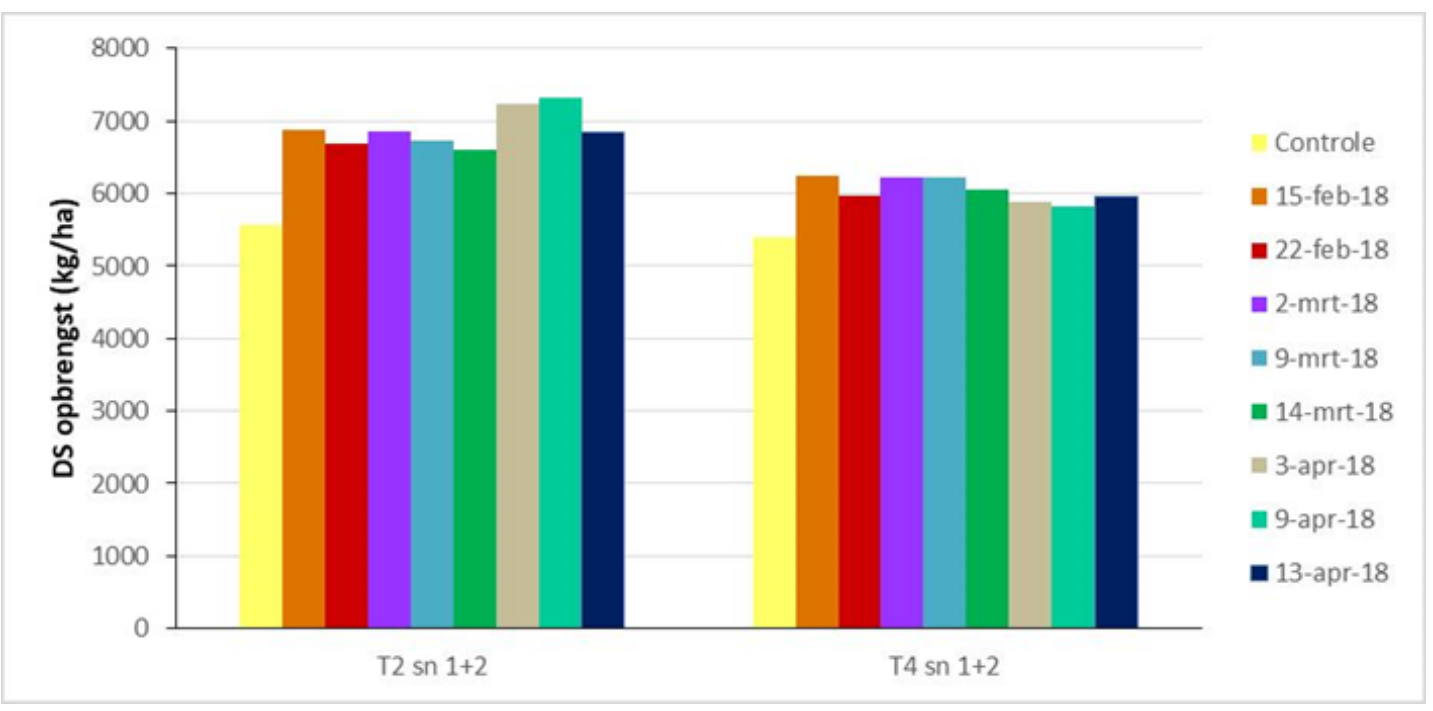

Figuur 6 Cumulatieve droge stofopbrengsten snede 1 en 2 bij verschillende tijdstippen van toedienen van kunstmest in het voorjaar bij een laag slootpeil op veen.

In Figuur 6 is te zien dat met name het object dat bemest is op 3 en 9 april de hoogste totale droge stofopbrengst als som van snede 1 en snede 2 laat zien, bij een gemaaide eerste snede op 25 april (T2). Als een eerste snede later wordt gemaaid (in dit geval op 15 mei; T4) zijn de opbrengstverschillen na de tweede snede relatief klein.

Kunstmest gecombineerd met drijfmest

De andere objecten zijn een combinatie van kunstmest, gegeven op een 4 tal tijdstippen met een vaste drijfmestgift van $25 \mathrm{~m}^{3}$ toegediend op 27 maart. De maaiopbrengsten van de eerste snede zijn voor 4 maaitijdstippen weergegeven in Figuur 7 als gemiddelde over beide slootpeilen (analoog aan de kunstmestobjecten in Figuur 4).

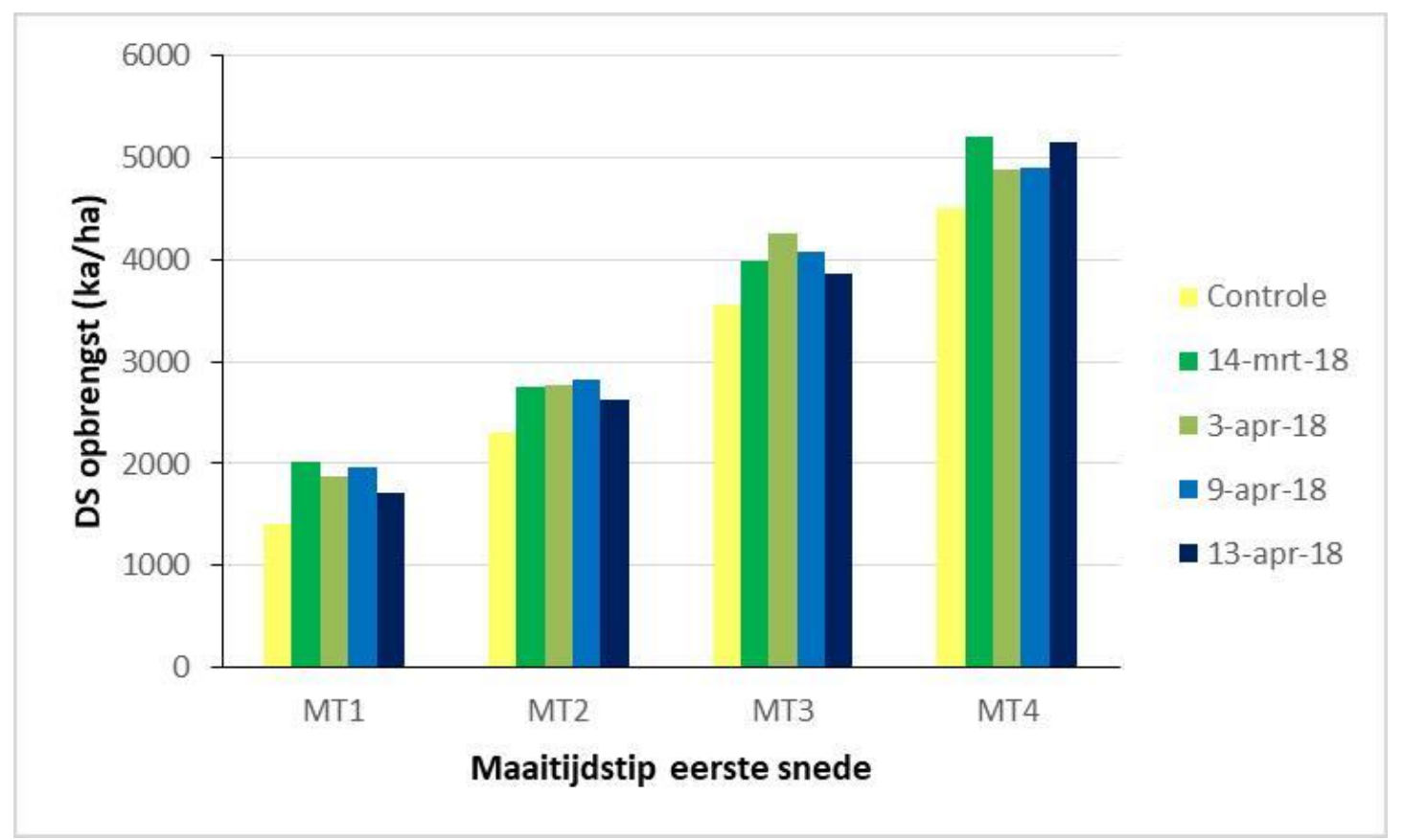

Figuur 7 Grasopbrengsten eerste snede op veen in 2018 bij 4 verschillende tijdstippen van toediening van kunstmest in combinatie met 25 m3 drijfmest gegeven op 27 maart op 4 maaitijdstippen gemiddeld bij 2 slootpeilen. 


\section{Drijfmestobjecten: toedieningstijdstip}

Op de drijfmestobjecten is een deel van de kunstmest vervangen door stikstof uit drijfmest. Er is een werking van $18 \mathrm{~kg} \mathrm{~N}$ verondersteld, waardoor de kunstmestgift is verlaagd tot $62 \mathrm{~kg} \mathrm{~N}$ in vergelijking tot de $80 \mathrm{~kg} \mathrm{~N}$ uit de kunstmestobjecten uit Figuur 4. Het blijkt dat het vervangen van een deel van de stikstof door drijfmest een nivellerend effect heeft op het effect van het toedieningstijdstip van de kunstmest. Waar in Figuur 4 op het eerste maaimoment (MT1) duidelijk sprake was van een lagere opbrengst bij de laat gestrooide objecten is dat beeld in Figuur 7 niet meer te zien.

Naast de combinatie kunstmest-drijfmest zijn een aantal additionele drijfmestobjecten bij een laag slootpeil aangelegd om een indicatie te krijgen van het effect van het tijdstip van toedienen van drijfmest op de opbrengst. De basisgift van $25 \mathrm{~m}^{3}$ per ha is toegediend op 7 maart, 27 maart en 19 april. Daarnaast zijn drie objecten opgenomen met een gift van $50 \mathrm{~m}^{3}$ per ha, waarbij deze bij twee objecten is gedeeld in twee giften van $25 \mathrm{~m}^{3}$ per ha met verschillende tijdstippen van toediening (zie Tabel 4). De $25 \mathrm{~m}^{3}$ objecten hebben op 13 april een aanvullende kunstmestgift gehad van $62 \mathrm{~kg} \mathrm{~N}$ per ha, de $50 \mathrm{~m}^{3}$ objecten hebben geen aanvulling gehad. In Figuur 8 zijn de opbrengsten van de eerste snede weergegeven bij twee oogsttijdstippen (T2; 25 april en T4; 15 mei).

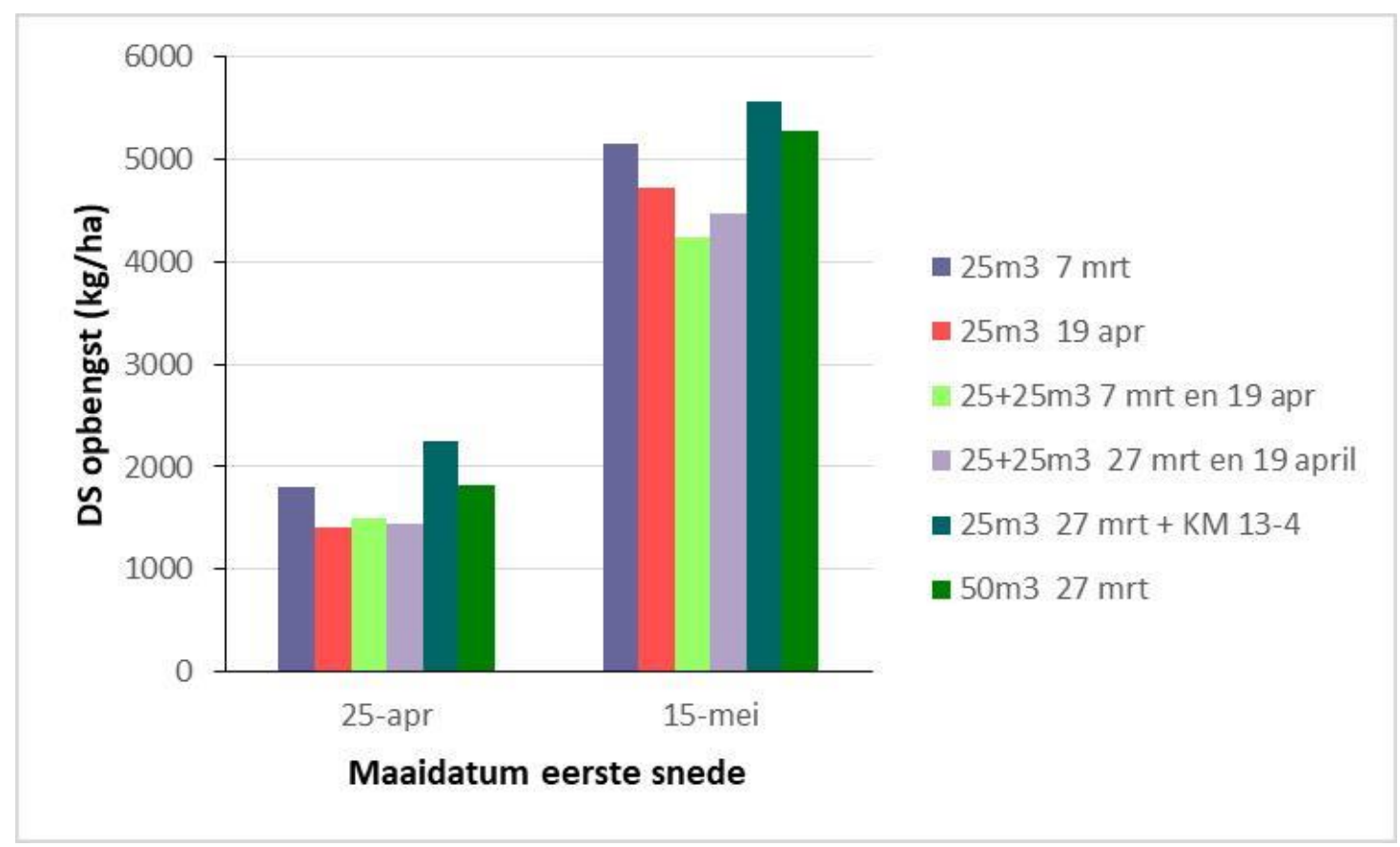

Figuur 8 Droge stofopbrengsten eerste snede bij verschillende toedieningstijdstippen en (gedeelde) hoeveelheden drijfmest bij een laag slootpeil op veen.

De eerste 2 kolommen in Figuur 8 laten zien dat de vroeg toegediende drijfmest (gift van $25 \mathrm{~m}^{3}$ ) de hoogste opbrengst geeft in verhouding tot de giftgrootte, zowel bij een vroege als een late oogst. Het delen van de gift van $50 \mathrm{~m}^{3}$ per ha had in de eerste snede een negatief effect. Alles in één keer toegediend op 27 maart gaf bij deze objecten de hoogste opbrengst op beide maaitijdstippen, zowel de 25 als de $50 \mathrm{~m}^{3}$ per ha. Omdat met name de latere toegediende drijfmest tot lagere opbrengsten heeft geleid, is gekeken of de nawerking van deze mest in de vervolgsnede tot uiting kwam. In Figuur 9 is dit weergegeven door de som van de eerste twee sneden weer te geven ( vervolgsnede niet bemest). 


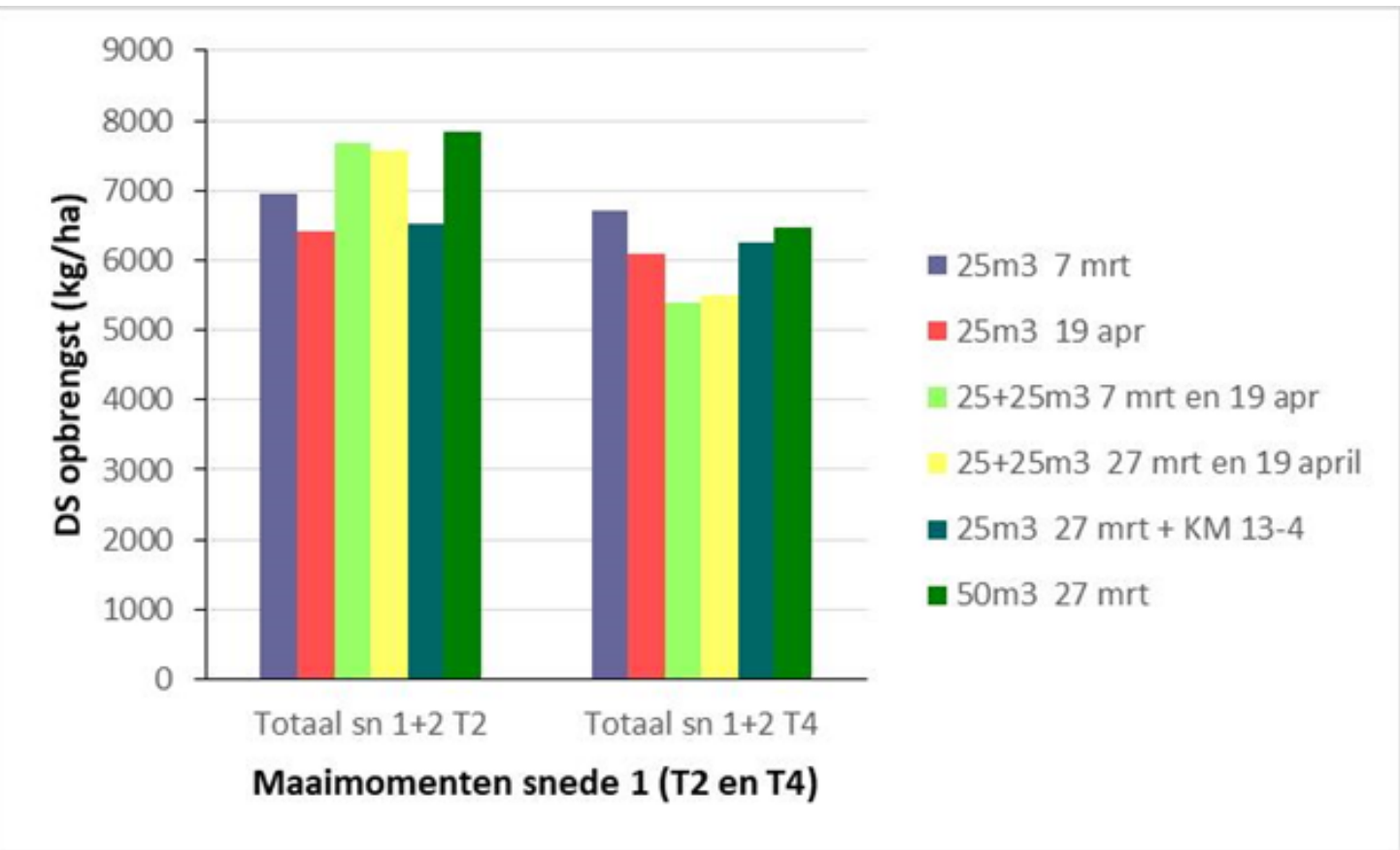

Figur 9 Droge stofopbrengsten som eerste + tweede snede bij verschillende toedieningstijdstippen en (gedeelde) hoeveelheden drijfmest in het voorjaar bij een laag slootpeil op veen.

Een deel van de in de eerste snede niet tot werking gekomen stikstof uit drijfmest is in de vervolgsnede wel tot werking gekomen. De gedeelde giften geven als som over twee sneden dezelfde opbrengst als bij de toediening in één keer, in elk geval bij vroeg maaien eerste snede (linker deel grafiek). De laat toegediende drijfmest geeft ook na twee sneden een lagere opbrengst indien de eerste snede vroeg gemaaid wordt. Als de eerste snede laat gemaaid wordt (rechter deel grafiek) is het beeld wisselend.

\subsection{Stikstofopbrengsten}

\section{Kunstmestobjecten}

De stikstof opbrengst is bepaald door de drogestofopbrengst te vermenigvuldigen met het stikstofgehalte. In Figuur 10 is de gemiddelde stikstofopbrengst weergegeven per toedieningstijdstip van de kunstmest en per maaimoment. Dit is het gemiddelde van de twee percelen (hoog en laag slootpeil), de kunstmest (KN T1 t/m KN T4 en KN T5 t/m KN T8) objecten en de twee herhalingen. Figuur 10 geeft een indruk van het effect van het bemestingstijdstip op de stikstofopbrengst van de eerste snede en de ontwikkeling van de stikstofopname in de tijd. De bemestingstijdstippen zijn weergegeven in de legenda. Het controleobject is niet bemest. De bemestingsdata voor de kunstmest waren 14 maart, 3 april, 9 april en 13 april (voor beide slootpeilen). De eerste snede is op vier tijdstippen geoogst: bij een laag slootpeil op 20 april, 25 april, 4 mei en 15 mei en bij een hoog slootpeil op 26 april, 4 mei, 11 mei en 15 mei. Omdat de figuur net als bij de drogestofopbrengst een gemiddelde weergeeft is het maaitijdstip genummerd. MT1 is dus het gemiddelde van de opbrengst op maaitijdstip 20 april bij laag slootpeil en 26 april bij hoog slootpeil. 


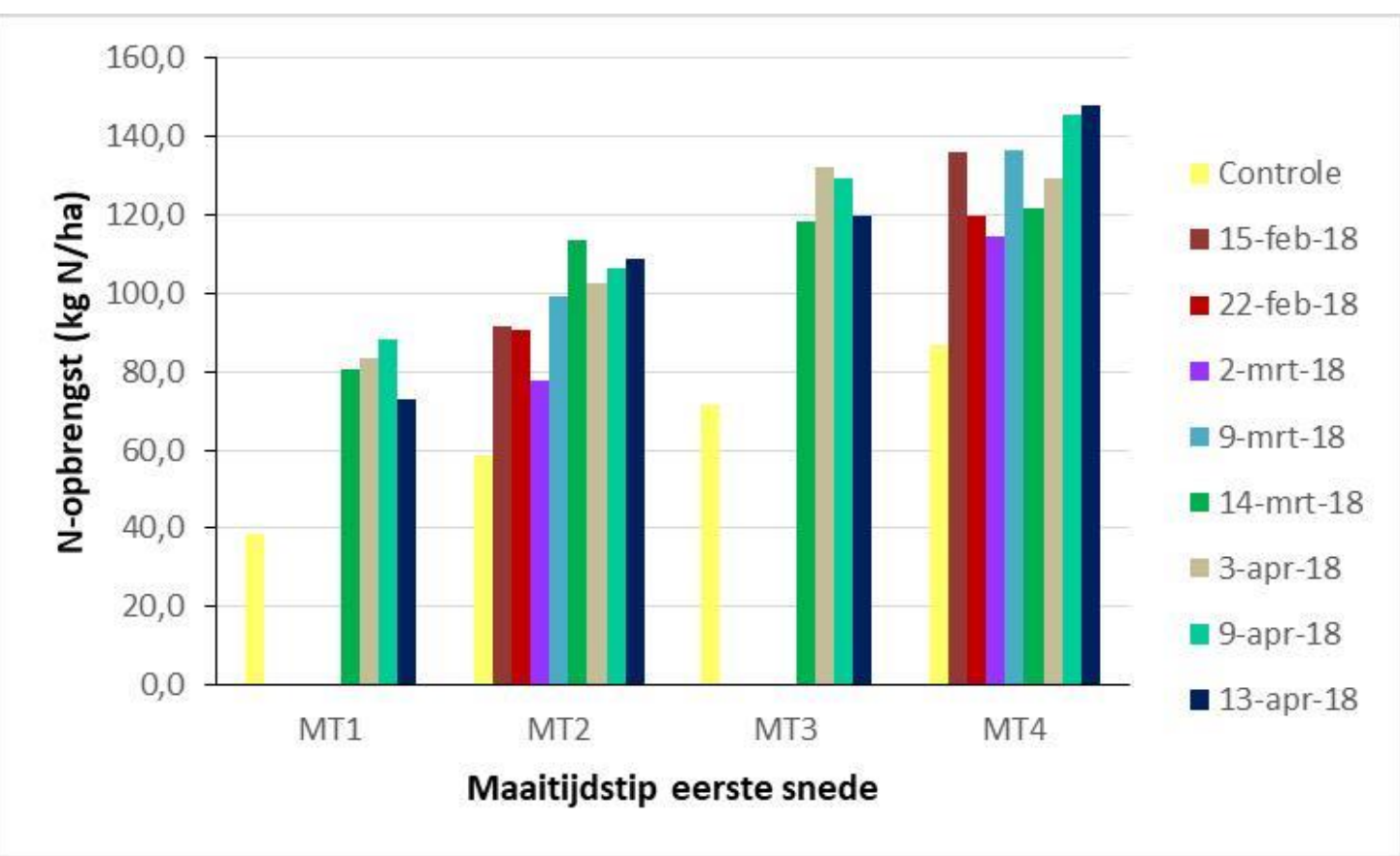

Figuur 10 Stikstofopbrengsten eerste snede op veen in 2018 bij vier verschillende tijdstippen voor toediening van stikstofkunstmest op vier maaitijdstippen gemiddeld bij twee slootpeilen.

De onbemeste velden hadden op alle oogsttijdstippen de laagste stikstofopbrengst, maar gaven duidelijk weer op welk moment het stikstofeffect van de gegeven kunstmest het grootst was (verschil bemeste velden en het onbemeste object). Het eerste maaitijdstip was op 20 april (laag slootpeil) en op 26 april (hoog slootpeil). Dit was één week respectievelijk bijna twee weken na de laatste stikstofgift (13 april). Net als bij de droge stofopbrengst bleef op dit maaitijdstip alleen bij de late gift van 13 april de stikstofopbrengst achter bij de andere strooimomenten. Dit lijkt er op te wijzen dat een deel van de toegediende stikstof nog niet opgenomen was. Voor MT2 zijn de stikstofopbrengsten van de vroeg gestrooide objecten lager dan die van de later (vanaf 9 maart) gestrooide objecten. De verschillen bij de objecten KNT1 t/m KNT4 die op het eerste maaitijdstip nog aanwezig waren zijn na een week bijgroei al verdwenen. Bij de op MT4 geoogste objecten was de stikstofopbrengst van de op 22 februari en 2 maart gestrooide objecten het laagst. In de statistische analyse is gekeken of de verschillen inderdaad significant zijn (zie paragraaf 3.5).

Omdat in de eerste snede op de diverse oogsttijdstippen toch enig verschil in stikstofopname aanwezig was tussen de objecten, is gekeken of de niet opgenomen stikstof mogelijk in de vervolgsnede alsnog opgenomen was. In Figuur 11 staat de stikstofopbrengst voor de tweede snede volgend op het tweede en vierde oogsttijdstip van de eerste snede, respectievelijk 25 april en 15 mei 2018. De cumulatieve stikstofopbrengst van de eerste en tweede snede staat in Figuur 12. 


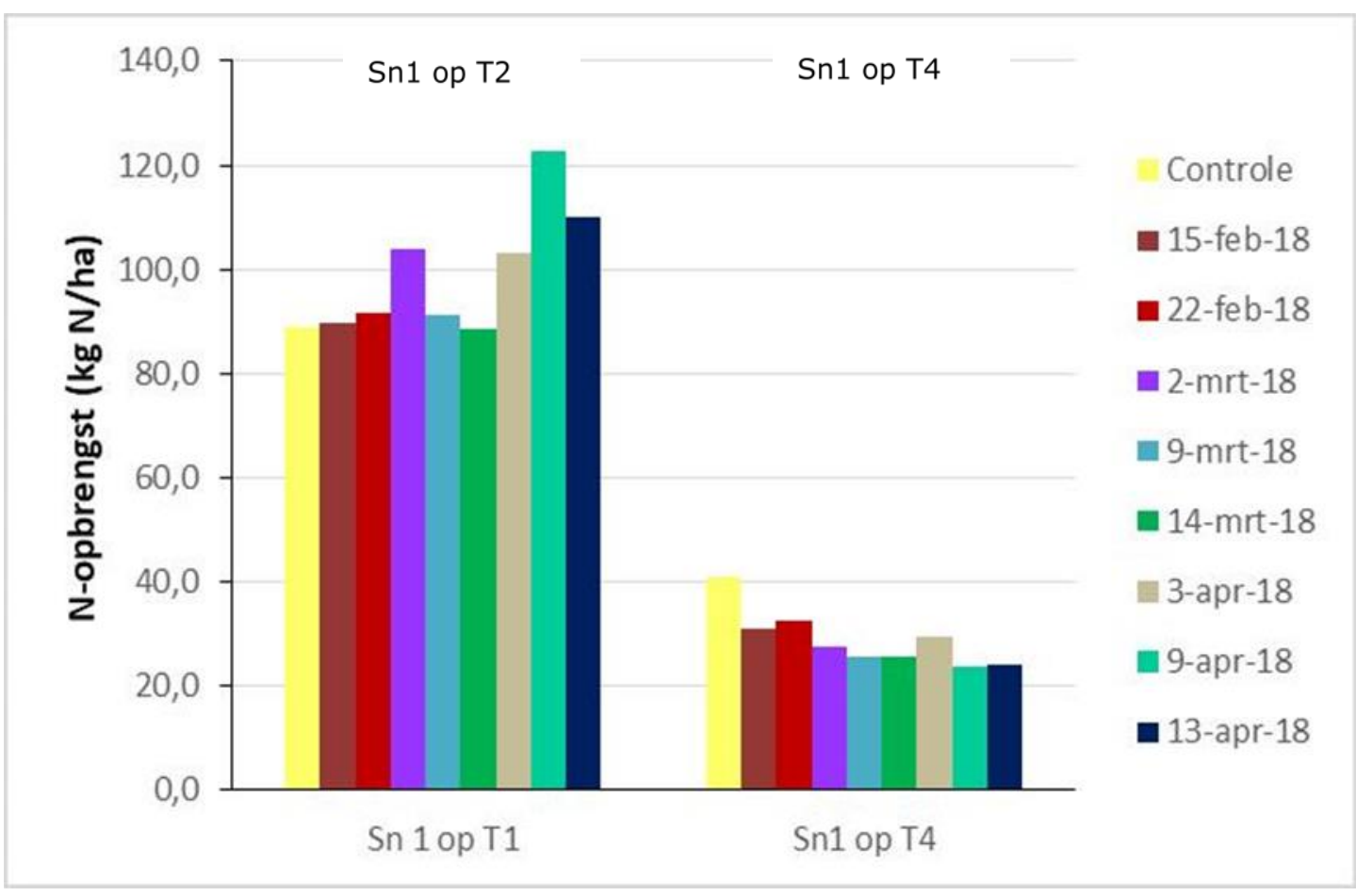

Figuur 11 Stikstofopbrengst snede 2, waarbij snede 1 geoogst werd op tijdstippen T2 en T4 en met stikstofkunstmest toegediend op acht data bij laag slootpeil op veengrond.

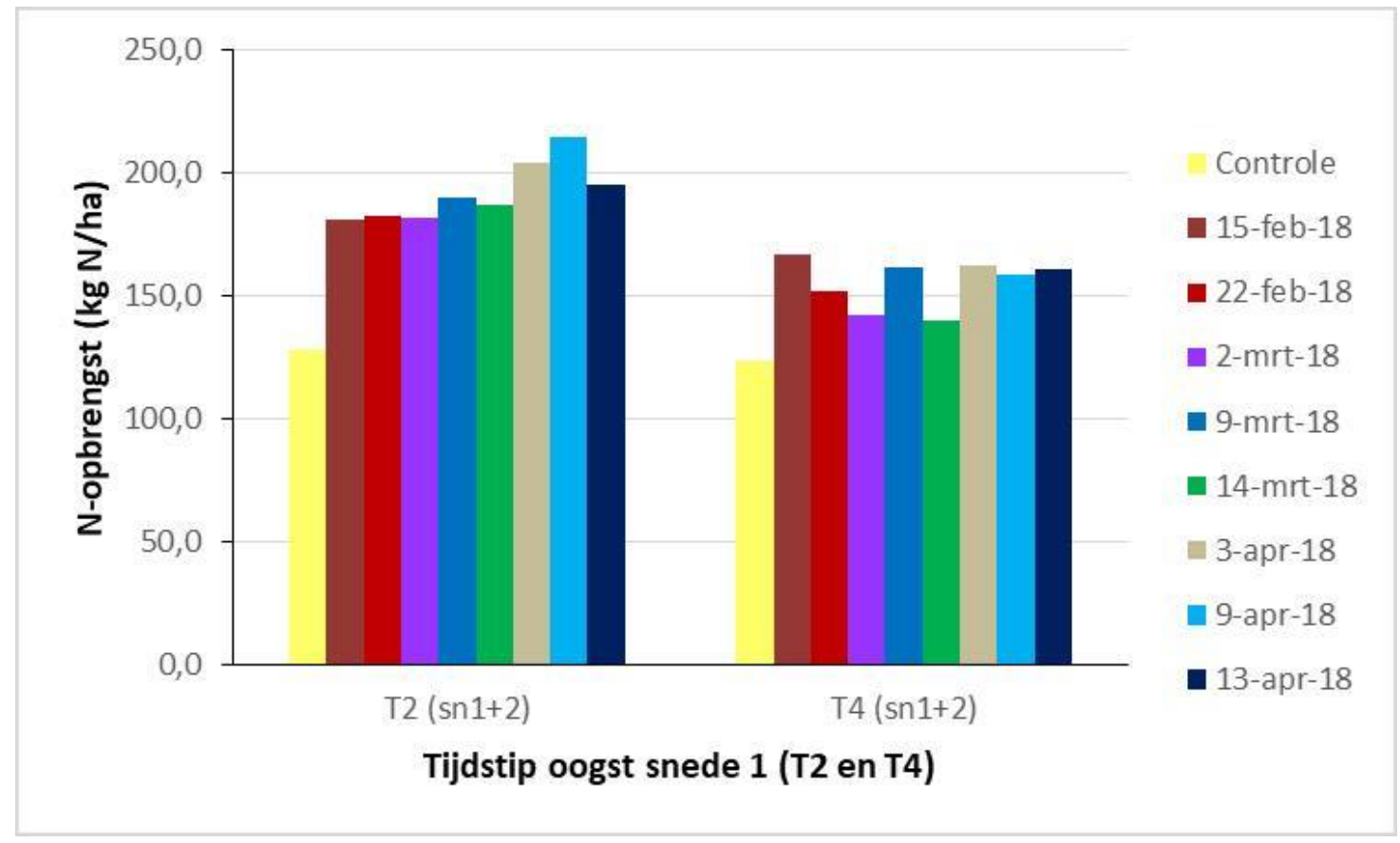

Figuur 12 Cumulatieve stikstofopbrengst snede 1 en snede 2 voor T2 en T4 van de eerste snede en de kunstmest op verschillende momenten is toegediend bij laag slootpeil op veengrond.

Alleen de heel vroeg gestrooide objecten gaven in de tweede snede een zelfde opbrengst als het onbemeste object (zie rechter deel van Figuur 11), waar vooral de laat bemeste objecten een hogere stikstofopbrengst laten zien. Wanneer de eerste snede zwaar wordt geoogst lijkt zelfs sprake van een negatief effect (hergroeivertraging) van alle bemeste objecten ten opzichte van het niet bemeste object. De laat toegediende kunstmest gaf overall (over snede $1+$ snede 2 ) de hoogste totale opbrengst wanneer snede 1 vroeg werd geoogst (Figuur 12). Of de visuele verschillen ook daadwerkelijk significant zijn, is in de volgende paragraaf (3.5) behandeld. 


\section{Gecombineerde kunstmest- en drijfmestobjecten}

In Figuur 13 wordt de stikstofopbrengst van de gecombineerde kunstmest met drijfmestobjecten weergegeven (de drijfmest is op alle objecten op 27 maart toegediend).

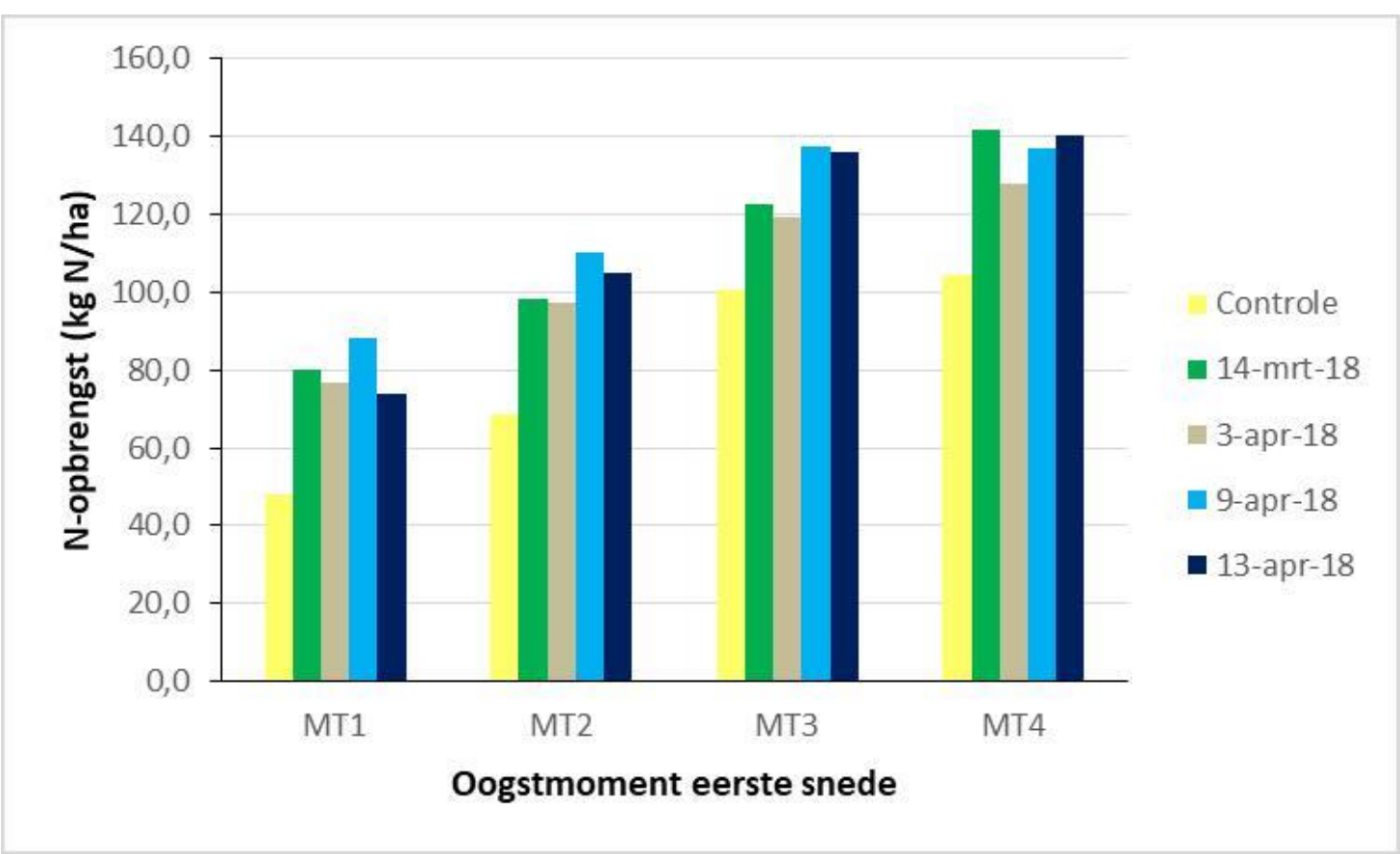

Figuur 13 Stikstof opbrengst eerste snede bij oogst op vier tijdstippen van gecombineerde kunstmest + drijfmest objecten gemiddeld over twee slootpeilen.

Bij het vervangen van een deel van de kunstmest door drijfmest is het effect van het moment van toedienen van de kunstmest nog kleiner geworden (vergelijking Figuur 13 met Figuur 10). Dit is vooral goed te zien wanneer de snede laat wordt geoogst (T4). Bij uitsluitend kunstmest (Figuur 10) gaven de laat bemeste objecten de hoogste opbrengst. Door een deel van de stikstofkunstmest te vervangen door stikstof uit drijfmest is dit beeld niet meer duidelijk aanwezig (Figuur 13).

Figuur 14 laat zien dat na de oogst van twee sneden, waarbij de eerste snede op twee verschillende tijdstippen is geoogst, de totale opbrengst bij alle bemeste objecten min of meer gelijk is. Dus is er uiteindelijk geen verschil in totale stikstofopbrengst bij verschillende momenten van toedienen van kunstmest. De laat toegediende kunstmest is blijkbaar allemaal benut. 


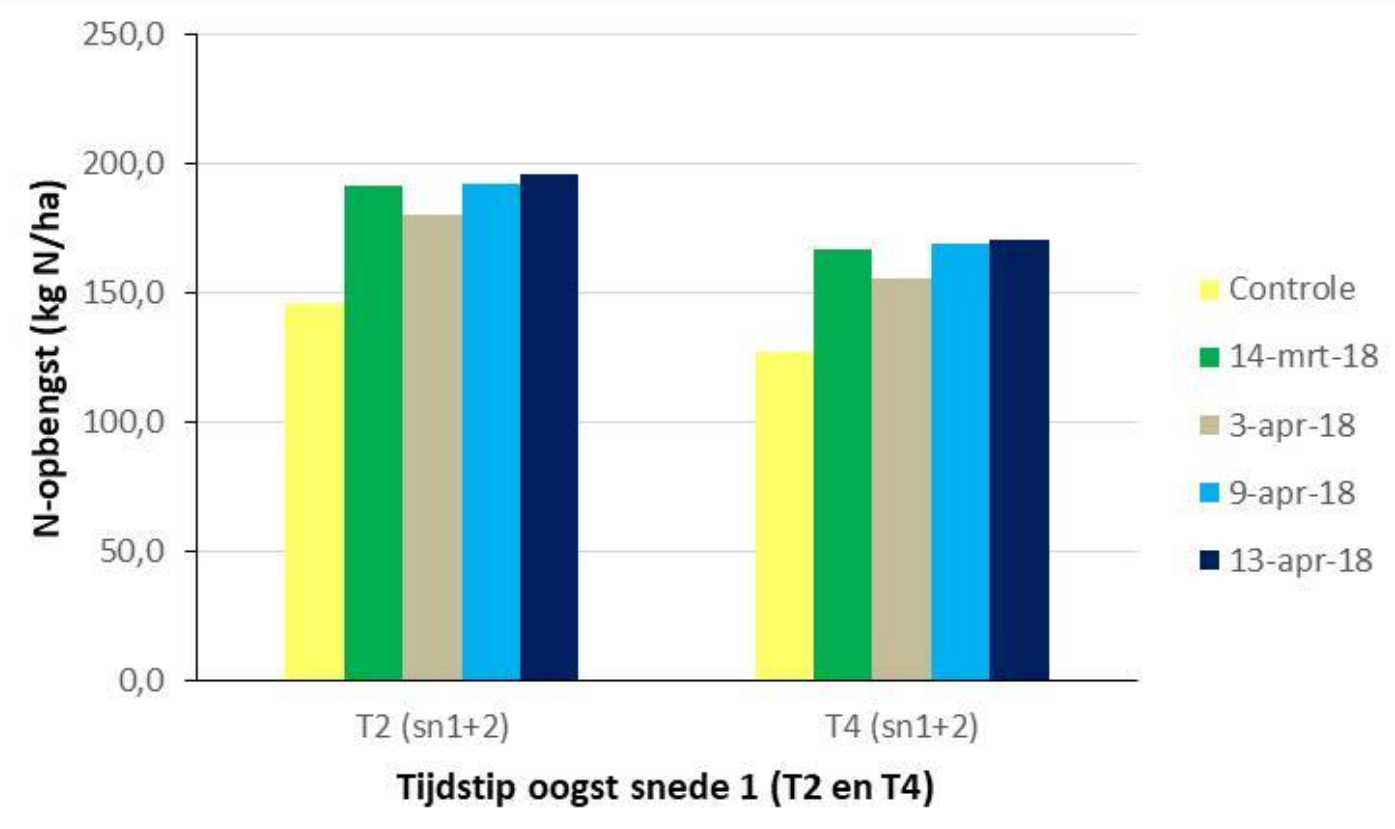

Figuur 14 Stikstofopbrengst eerste en tweede snede samen bij verschillende tijdstippen van toediening stikstofkunstmest in combinatie met een drijfmestgift in het voorjaar op veengrond als gemiddelde van twee slootpeilen.

Toedieningstijdstip drijfmest en gedeelde drijfmestgiften

De extra objecten, waarbij de drijfmest op drie momenten in het voorjaar is toegediend ( $25 \mathrm{~m}^{3}$ per ha) en ook $50 \mathrm{~m}^{3}$ per ha, waarbij deze in één keer en gedeeld is toegediend, geven in de eerste snede een stikstofopname zoals is weergegeven in Figuur 15.

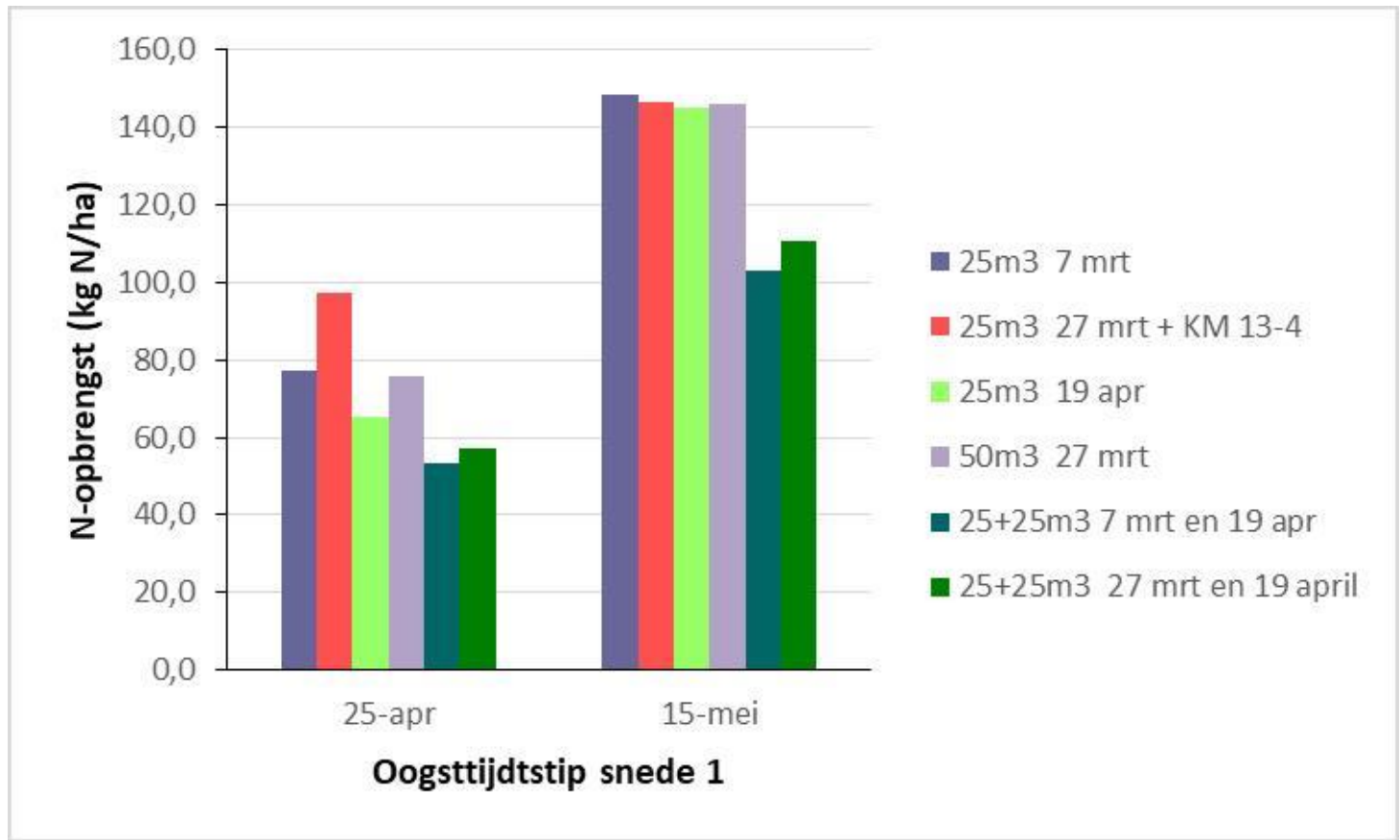

Figuur 15 Stikstofopbrengst eerste snede bij twee maaimomenten (licht en zwaar) bij toedienen van drijfmest op verschillende momenten bij laag slootpeil op veengrond. 
Bij de vroege oogst geeft de drijfmest, die op 27 maart is toegediend, de hoogste stikstofopbrengst, zelfs hoger dan het $50 \mathrm{~m}^{3}$ object. Het laatst genoemde object heeft echter alleen drijfmest toegediend gekregen, waar de $25 \mathrm{~m}^{3}$ een aanvulling heeft gehad van $62 \mathrm{~kg} \mathrm{~N}$ uit kunstmest, dus een hogere stikstofopbrengst mag ook worden verwacht door de snellere werking van kunstmest. Wanneer de snede later wordt geoogst verdwijnen de verschillen in toedieningstijdstip en geeft het object met $50 \mathrm{~m}^{3}$ drijfmest zonder extra kunstmest zelfs dezelfde opbrengst als de objecten waar $25 \mathrm{~m}^{3}$ drijfmest is toegediend, aangevuld met $62 \mathrm{~kg} \mathrm{~N}$ per ha uit kunstmest. Wel blijven de gedeelde giften zowel bij vroege als bij late oogst achter. In Figuur 16 is het totaal van de $\mathrm{N}$-opbrengst van de eerste en tweede snede weergegeven.

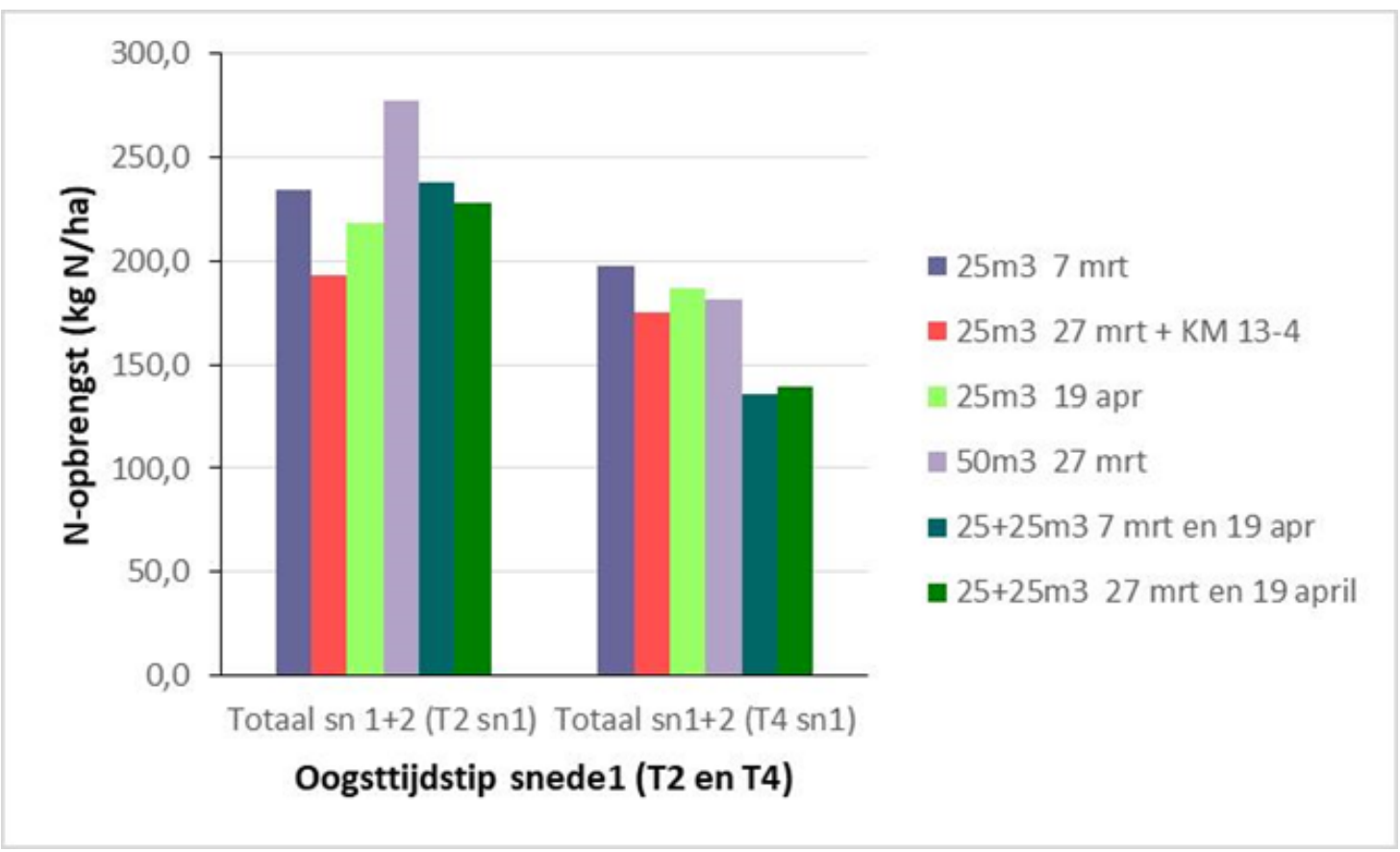

Figuur 16 Stikstofopbrengst som eerste en tweede snede bij verschillende momenten van toedienen van drijfmest op veen bij een laag slootpeil.

In het algemeen zijn de verschillen klein, maar opvallend is dat zelfs na de oogst van twee sneden de stikstofopbrengst bij de gedeelde gift achterblijft. Mogelijk heeft structuur of zodebeschadiging een rol gespeeld, aangezien bij een gedeelde gift twee keer over een perceel gereden wordt.

\subsection{Statistische analyse}

Gekozen is voor een analyse op onderdelen omdat de proef niet gebalanceerd was; niet alle objecten lagen op beide percelen en niet alle objecten hadden hetzelfde oogstschema. De objecten met alleen kunstmest en de objecten waarbij kunstmest is aangevuld met op één tijdstip ( 27 maart, $25 \mathrm{~m}^{3}$ ) toediening van drijfmest zijn geanalyseerd met REML, omdat niet alle objecten hetzelfde maaischema hadden. De (toegevoegde) vroeg gestrooide objecten zijn alleen op tijdstip T2 en T4 gemaaid en alleen bij een laag slootpeil uitgevoerd. De herhalingen en het veldnummer zijn opgenomen als factor in het Random deel. Het perceel (vertaald als slootpeil-effect), het tijdstip van toedienen van de kunstmest, het al dan niet gebruiken van drijfmest, het oogstmoment en de interacties tussen al deze factoren zijn opgenomen in het Fixed model. Een eerste analyse is uitgevoerd inclusief het onbemeste controle object. Aangezien aan het onbemeste object geen bemestingstijdstip verbonden was, is in een tweede analyse het onbemeste object buiten de analyse gehouden om een zuiverder beeld te krijgen van het effect van het bemestingstijdstip. 


\subsubsection{Analyse droge stofopbrengst}

Van de hoofdeffecten had factor "perceel" een significant effect op de opbrengst. Mogelijk door een wat droger voorjaar lag de gemiddelde opbrengst bij een hoog slootpeil significant hoger $(p<0.001)$ dan bij een laag slootpeil. Het oogstmoment had een significant effect op de opbrengst; later maaien gaf een hogere opbrengst, waarbij het gewas bij een hoog slootpeil in eerste instantie sneller groeide dan bij een laag slootpeil. Bij het laatste oogstmoment en een laag slootpeil had de groei een inhaalslag gemaakt en was de opbrengst bij een laag slootpeil hoger dan bij een hoog slootpeil. Het toedienen van drijfmest had alleen bij een hoog slootpeil een significant negatief effect op de opbrengst $(p=0.003)$. Het tijdstip van toedienen van de kunstmest had een significant effect op de opbrengst. Het onbemeste object had een significant lagere opbrengst $(p<0.001)$ dan de overige objecten. De resultaten van de REML analyse van de drogestofopbrengsten staat in Tabel 7.

Tabel 7 Resultaten REML analyse droge stofopbrengst (inclusief onbemest object).

\begin{tabular}{lccccc} 
Fixed term & Wald statistic & n.d.f. & F statistic & d.d.f. & $F \mathrm{pr}$ \\
Perceel & 5391.98 & 2 & 2695.75 & 126.2 & $<0.001$ \\
\hline Oogstmoment & 2382.17 & 3 & 794.06 & 125.2 & $<0.001$ \\
\hline Drijfmest & 26.36 & 1 & 26.36 & 92.9 & $<0.001$ \\
\hline Datum gift & 16.73 & 7 & 2.39 & 125.6 & 0.025 \\
\hline Perceel . Oogstmoment & 119.92 & 3 & 39.97 & 125.4 & $<0.001$ \\
\hline Perceel . Drijfmest & 8.92 & 1 & 8.92 & 126.6 & 0.003 \\
\hline
\end{tabular}

Bij het weglaten van het onbemeste object, om het contrast tussen bemestingstijdstippen van de bemeste objecten beter te kunnen toetsen, week het laatst bemeste object (13 april) significant $(p=0.006)$ af van de andere bemestingstijdstippen (opbrengst was $300 \mathrm{~kg} \mathrm{ds} / \mathrm{ha}$ lager; niet in Tabel 7 weergegeven).

Er was geen verschil in effect van de datum van de mestgift, al dan niet gecombineerd geven van drijfmest in combinatie met het oogstmoment, op de drogestofopbrengst. Er was geen sprake van een interactie-effect van de datum kunstmestgift met de andere factoren. Alle niet significante effecten zijn uit het model gehaald.

\subsubsection{Analyse stikstofopbrengst}

Ook bij de analyse van de stikstofopbrengst gaf het onbemeste object een significant lagere stikstofopbrengst dan de overige objecten en is in de vervolgstap dit object uit de analyse gelaten. De uitkomsten van de analyse met alle objecten (inclusief onbemest) is weergegeven in tabel 8 .

Tabel 8 Uitkomst REML analyse stikstof stofopbrengst (inclusief onbemest object).

\begin{tabular}{lccccc} 
Fixed term & Wald statistic & n.d.f. & F statistic & d.d.f. & F pr \\
Perceel & 3057.7 & 2 & 1528.47 & 124.6 & $<0.001$ \\
\hline Oogstmoment & 384.5 & 3 & 128.17 & 125.4 & $<0.001$ \\
\hline Drijfmest & 2.32 & 1 & 2.32 & 64.5 & 0.133 \\
\hline Datum gift & 21.09 & 7 & 3.01 & 125.7 & 0.006 \\
\hline Perceel . Drijfmest & 5.73 & 1 & 5.73 & 126.9 & 0.018 \\
\hline Perceel . Datum gift & 15.47 & 3 & 5.16 & 125.1 & 0.002 \\
\hline
\end{tabular}

Ook hier was sprake van een significant perceel/slootpeil effect $(p<0.001)$; verrassend gaf perceel PR08 (hoog slootpeil) gemiddeld de hoogste stikstofopbrengst. Ook het oogstmoment was significant; 
later geoogst gras geeft een hogere stikstofopbrengst. Het effect van het geven van drijfmest als vervanging van een deel van de stikstofkunstmest gaf bij een hoog slootpeil een significant $(p=0.018)$ lagere stikstofopbrengst. Het effect van het moment van kunstmest strooien gaf een interactie met het perceel $(p=0.002)$. Dat betekent dat de reactie bij hoog slootpeil anders was dan bij laag slootpeil. In $z$ 'n algemeenheid gaf het strooien van kunstmest vanaf 9 maart bij een laag slootpeil een hogere stikstofopbrengst dan strooien voor 9 maart. Echter, vanaf deze datum maakte het strooimoment niet uit voor de stikstofopbrengst. Bij hoog slootpeil lag dit anders. Helaas waren de vroege strooimomenten hier niet aangelegd, maar de hoogste stikstofopbrengsten werden behaald bij de late strooimomenten. Met name het strooimoment op 13 april gaf een opvallend beeld. Hier werd de op één na hoogste stikstofopbrengst behaald bij een significant lagere drogestofopbrengst. Dit kan betekenen dat wel veel stikstof was opgenomen, maar nog niet volledig was benut voor drogestof.

\subsubsection{Analyse Bemestingstijdstip drijfmest al dan niet in gedeelde gift.}

In dit deel is gekeken naar het toedieningstijdstip van de drijfmest, maar ook of het delen van grote drijfmestgiften in twee toedieningstijdstippen een positief effect had. De gedeelde giften hadden alleen betrekking op de $50 \mathrm{~m}^{3}$ objecten. Kijkend naar alleen de hoeveelheid ( 25 of $50 \mathrm{~m}^{3}$ ) kon de analyse alleen met REML worden uitgevoerd (ongebalanceerde data). In de eerste snede gaf een hogere drijfmestgift een lagere drogestofopbrengst, maar dat kan mede het gevolg zijn geweest van het feit dat deze objecten een aanvulling hebben gehad van $62 \mathrm{~kg} \mathrm{~N}$ per ha uit kunstmest. In de tweede snede was de drogestofopbrengst daarentegen hoger.

Het tijdstip van toediening had een significant effect op de drogestofopbrengst, zowel op het eerste als tweede snede (ANOVA, alle objecten samen geanalyseerd; $p=0.002$ ). Vroeg toedienen van drijfmest gaf hogere drogestofopbrengsten dan laat toedienen, zelfs als op het latere tijdstip de hoeveelheid mest groter was. De hoogste opbrengsten werden behaald bij de gift die op 27 maart is toegediend, maar deze opbrengst verschilde niet significant van de gift op 7 maart of van de dubbele gift. Dit verschil was zowel bij vroege als late oogst van de eerste snede aanwezig.

Opvallend is dat de $50 \mathrm{~m}^{3}$ objecten die in de eerste snede vroeg zijn geoogst in de tweede snede een significant hogere drogestofopbrengst gaven dan de andere objecten, waarbij het delen van de $50 \mathrm{~m}^{3}$ geen effect heeft gehad. Dit zou kunnen wijzen op nawerking, maar bij de later geoogste objecten was hier geen sprake van en werkte de $50 \mathrm{~m}^{3}$ dus niet beter dan de $25 \mathrm{~m}^{3}$.

De stikstofopbrengsten lieten een zelfde beeld zien als de drogestofopbrengsten. Enige verschil was dat de $\mathrm{N}$-opbrengst van de objecten die in de eerste snede laat waren geoogst in de tweede snede geen significant verschillende $\mathrm{N}$-opbrengsten lieten zien. 


\section{$4 \quad$ Discussie}

\subsection{Anticiperen op bodemtemperatur}

Het tijdstip van kunstmest strooien is in basis bepaald aan de hand van de bodemtemperatuur (uitgezonderd additionele objecten). Doel was om de eerste gift te gegeven als de bodemtemperatuur drie opeenvolgende dagen boven de 5 graden Celsius zou komen, gemeten met een bodemtemperatuursensor op $20 \mathrm{~cm}$ diepte. Door het grillige verloop van de temperatuur duurde het relatief lang voordat drie opeenvolgende dagen met deze bodemtemperatuur voorkwamen. Door op $20 \mathrm{~cm}$ diepte te meten werd het meest grillige verloop van de luchttemperatuur wel enigszins gedempt, maar de temperatuurverschillen in de buitenlucht waren erg groot in het betreffende voorjaar, waardoor ook op $20 \mathrm{~cm}$ nog sprake was van variatie in temperaturen. Na een erg koude start van maart, steeg de temperatuur van de bodem snel en werd in een relatief korte periode aan de eerste temperatuurklasse voldaan. Rond 20 maart kwam een nieuwe koude periode, waardoor de bodemtemperatuur weer daalde en de volgende temperatuurklasse op zich liet wachten. Toen de temperatuur begon te stijgen moest betrekkelijk snel achter elkaar gestrooid worden. Er zijn echter meer effecten aan de orde dan alleen de bodemtemperatuur op het moment van strooien, omdat er wel opbrengstverschillen geconstateerd werden, maar deze niet konden worden gerelateerd aan de combinatie bodemtemperatuur-toedieningstijdstip.

Voor de proefuitvoering zou het meest ideaal geweest zijn dat de bodemtemperatuur in het voorjaar een constante langzame stijging vertoond zou hebben, waardoor de tijdstippen netjes in de tijd verdeeld zouden zijn. De praktijk is echter anders en deze schommelingen kunnen een effect hebben gehad op de uitkomsten. Ook geeft dit aan dat het anticiperen op de ontwikkeling van de bodemtemperatuur gecompliceerder is dan het lijkt. Er was alleen zicht op het actuele temperatuurverloop, maar niet van de bodemtemperatuur in de nabije toekomst, bijvoorbeeld de weersverwachtingstermijn.

Opvallend was dat tussen het hoge en lage slootpeil geen verschil was in ontwikkeling van de bodemtemperatuur. Blijkbaar waren beide betreffende percelen dusdanig nat dat dit geen verschil opleverde. Wel was het perceel bij het hoge slootpeil dusdanig natter, dat drijfmest aanzienlijk later uitgereden kon worden.

Tsom

Volgens het bemestingsadvies dient gestrooid te worden tussen een Tsom van 180 en 280 graden Celsius, waarbij tevens rekening gehouden dient te worden met de weersomstandigheden. Wordt veel neerslag verwacht, dan moet de gift worden uitgesteld. Meestal kan dit zonder buiten het optimale Tsom traject te geraken. De Tsom van 180 graden Celsius werd in 2018 redelijk vroeg bereikt (op 12 februari) door de relatief warme maand januari, zie Figuur 17. Direct na het bereiken van de 180 graden Celsius grens werd het echter koud en bleef de Tsom meer dan drie weken min of meer steken op 200 graden Celsius. Het 280 graden Celsius moment werd bereikt op 20 maart. De totale periode die wordt aangemerkt als optimaal strooimoment bedroeg daarmee bijna zes weken. Binnen deze periode zijn vijf van de acht strooimomenten geweest. Dit waren ook juist de strooimomenten met de kleinste verschillen en de (relatief) hoogste opbrengsten. Het lijkt er dus op dat in 2018 Tsom tot een correct advies heeft geleid. Met name de later gestrooide objecten bleven in opbrengst bij vroeg oogsten wat achter. Wanneer echter deze objecten de tijd gehad zouden hebben om door ter groeien naar een behoorlijke zware maaisnede, dan zouden deze verschillen wellicht verdwenen zijn. 


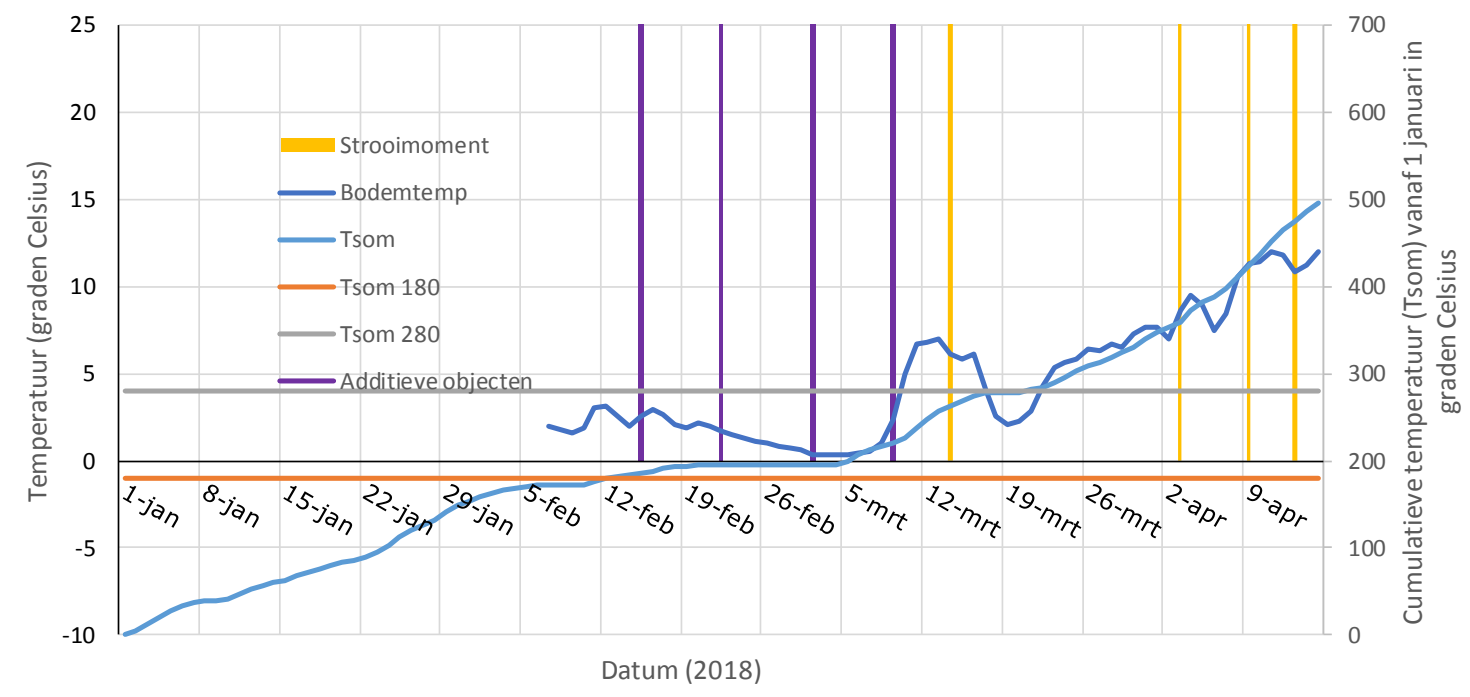

Figuur 17 Ontwikkeling Tsom 2018 en relatie met gekozen strooimomenten.

\subsection{Opbrengsten}

Door het relatief warme voorjaar is het gras explosief gegroeid. De eerste snede zou eigenlijk licht gemaaid moeten worden, maar toen was de drijfmest nog maar net uitgereden door onvoldoende draagkracht. Het eerste maaimoment is daarom iets later uitgevoerd dan voorzien, met als gevolg een relatief hogere opbrengst.

Door op meer momenten in een snede te maaien is een beeld gekregen van de groeisnelheid (ontwikkeling) van het gras in het voorjaar. Daarmee is het mogelijk geweest om te toetsen of sprake was van een snelle opname direct na toediening en of de tijd (groeiduur) een verschil in toedieningstijdstip kan compenseren. Uit de resultaten is gebleken dat dit mogelijk is. De vroeg toegediende kunstmest gaf vooral op het eerste oogstmoment nog een licht hogere opbrengst, maar dit positieve effect verdween op de volgende oogstmomenten. Omdat de verschillen in de eerste snede al marginaal waren, was ook niet veel verschil in nawerking te verwachten, hetgeen ook is gebleken uit de opbrengsten van de tweede snede, waar nauwelijks verschil in optrad.

Door de geringe opbrengstverschillen werd waarschijnlijk ook weinig verschil in stikstofopbrengst (en daarmee in het eiwitgehalte) gemeten. Er was geen sprake van luxe consumptie van stikstof door gras (behalve mogelijk bij het laatste toedieningstijdstip).

De objecten waar $25 \mathrm{~m}^{3}$ per ha drijfmest aanvullend met $62 \mathrm{~kg} \mathrm{~N}$ per ha uit kunstmest is toegediend hadden een hogere opbrengst in de eerste snede dan de objecten waar (alleen) $50 \mathrm{~m}^{3}$ per ha drijfmest is toegediend. Dit is mogelijk veroorzaakt door de betere werking van kunstmest en de iets hogere (werkzame) dosering van stikstof bij de gecombineerde objecten. De tweede snede liet echter een hogere opbrengst zien bij de $50 \mathrm{~m}^{3}$ objecten. Er blijkt dus meer na te werken van de $50 \mathrm{~m}^{3}$, maar er is ook minder stikstof opgenomen in de eerste snede, door de lagere opbrengst. Het delen van de eerste gift heeft een negatief effect op de drogestofopbrengst in de eerste snede. Dit werd in de tweede snede echter niet goedgemaakt.

De overall resultaten van deze proef zijn niet consistent. Er is geen duidelijk beeld dat eerder toegediende mest een significant hogere (of lagere) opbrengst geeft dan laat toegediende mest. Ook is er geen duidelijke 'lijn' te ontdekken: een relatie tussen toedieningstijdstip en opbrengst. Daarvoor 
wisselen de opbrengst tussen het eerste en laatste toedieningstijdstip te veel. De vraag is of één jaar onderzoek voldoende was om de hypothese goed te kunnen toetsen. Echter, zelfs een tweede jaar onderzoeksjaar met mogelijk geheel andere resultaten zal waarschijnlijk ook nog onvoldoende inzicht geven om de onderzoeksvraag te beantwoorden. 


\section{$5 \quad$ Conclusie}

Het slootpeil had tegen de verwachting in geen invloed op de ontwikkeling van de bodemtemperatuur. De bodemtemperatuur op $20 \mathrm{~cm}$ diepte laat een vlakker verloop in de tijd zien dan die op $10 \mathrm{~cm}$ onder maaiveld en is daarom geschikter om als basis te dienen. In deze laag wordt de invloed van dag- en nachtverschillen, maar ook grote schommelingen van de luchttemperatuur gedempt. Daarmee geeft meten op $20 \mathrm{~cm}$ diepte een betere referentie.

Ondanks dat er veel verschil is tussen het moment van de vroegste stikstofgift (15 februari) en de laatste stikstofgift (13 april) is er geen significant effect van het bemestingstijdstip op de drogestofopbrengst gemeten. De veronderstelde streefwaarde voor bodemtemperatuur van 8 graden Celsius bleek in 2018 op veengrond niet de indicator te zijn voor het optimale bemestingstijdstip. Vroege toediening leidde tot een relatief hoge drogestof- en stikstofopbrengst. Dit betekent dat bij gebruik van grasland vroeg in het voorjaar, zoals de percelen die als eerste geweid gaan worden, kunstmest relatief vroeg gegeven moet worden.

Het toedienen van een dubbele hoeveelheid drijfmest ( $50 \mathrm{~m}^{3}$ in plaats van $25 \mathrm{~m}^{3}$ per ha aangevuld met $62 \mathrm{~kg} \mathrm{~N}$ per ha uit kunstmest) gaf geen hogere opbrengst. De extra gegeven drijfmest is niet tot de zelfde werking gekomen als de met kunstmest aangevulde objecten met $25 \mathrm{~m}^{3}$ per ha drijfmest. De drijfmest die op de tijdstippen 'vroeg' en 'midden' werden toegediend hadden een vergelijkbaar effect op de drogestof- en stikstofopbrengst, maar de 'laat' toegediende drijfmest gaf een lagere opbrengst. Het delen van een drijfmestgift in het voorjaar leidde niet tot een verbetering van de benutting, maar liet zelfs lagere opbrengsten zien. 


\section{Literatuur}

GenStat 16th edition, 2013. VSN International Ltd

Gollenbeek, L.R., Hoving, I.E. 2016. Voorjaarsbemestingsadvies grasland op basis van bodemtemperatuur; Deskstudie. Wageningen Livestock Research, Rapport 1004. 


\section{Bijlage 1 Samenvatting deskstudie}

Het huidige bemestingsadvies voor gras in het voorjaar maakt gebruik van de temperatuursom (Tsom) om het optimale tijdstip van bemesting voor kunstmest vast te stellen. In de praktijk wordt de Tsom als een te grove richtlijn ervaren veelal doordat de Tsom eerder wordt bereikt dan dat gras daadwerkelijk gaat groeien, zoals dat in het voorjaar van 2016 het geval was. Er is zodoende behoefte aan een specifiekere maat voor het optimale bemestingstijdstip. In de praktijk wordt reeds geëxperimenteerd met het meten van bodemtemperatuur om de start van de grasgroei te kunnen voorspellen.

In het voorliggende rapport staan de resultaten van een deskstudie die uitgevoerd is om inzicht te krijgen in de relatie tussen bodemtemperatuur, het tijdstip van bemesting en gewasgroei afhankelijk van de grondsoort en het type meststof en invloed van overige omstandigheden zoals vocht en neerslagpatroon. De studie richtte zich alleen op de voorjaarsbemesting van grasland onder Nederlandse omstandigheden. De primaire onderzoeksvraag is of het meten van de actuele bodemtemperatuur een betere basis voor het voorjaarsbemestingsadvies voor grasland dan het toepassen van Tsom.

De Tsom is ontwikkeld op resultaten van vele jaren van onderzoek naar grasgroei (periode 19601983). In deze proeven is op verschillende grondsoorten en tijdstippen voor de eerste snede bemest met stikstofkunstmest, vooral met kalkammonsalpeter (KAS). Het tijdstip van bemesten is afhankelijk gesteld van de streefopbrengst van de eerste snede. De optimale Tsom wordt over het algemeen in februari/maart bereikt. De Tsom is gemiddeld over de jaren een redelijke schatter voor het gewenste bemestingstijdstip, maar kan in individuele weerjaren behoorlijk afwijken.

Als alternatief voor de Tsom wordt in de praktijk geëxperimenteerd met het meten van bodemtemperatuur op ongeveer $10 \mathrm{~cm}$ diepte. De meetdiepte zal invloed hebben op de voorspelling, enerzijds vanwege het dag-nachtritme dat teruggevonden wordt in de meetresultaten en anderzijds de worteldiepte. Het merendeel van de wortelmassa bevindt zich namelijk in de laag van $0-10 \mathrm{~cm}$. Ook is niet duidelijk of de bodemtemperatuur als enige parameter voldoende is om de start van de grasgroei te voorspellen.

In de onderzoeken die gebruikt zijn voor de ontwikkeling van de Tsom is geen bodemtemperatuur gemeten. Verder werd slechts één onderzoek gevonden waarin de bodemtemperatuur gemeten is in relatie tot grasgroei. Hierin werden lineaire verbanden gevonden tussen bodemtemperatuur op $10 \mathrm{~cm}$ diepte en de groei van stengels en bladeren bij bodemtemperaturen tussen de 3 en $10^{\circ} \mathrm{C}$. De conclusie was echter dat dit verband niet causaal hoeft te zijn aangezien straling en daglengte ook belangrijke factoren zijn. Natte gronden staan bekend als late gronden. Het is zodoende aannemelijk om te veronderstellen dat bodemtemperatuur een belangrijke rol speelt in de start van de groei.

In februari is de kans op een verschil in ontwikkeling van de Tsom en de bodemtemperatuur het grootst. De bodemtemperatuur kan worden berekend op basis van de luchttemperatuur, echter het betreft een empirische relatie die een benadering is van de werkelijkheid. Factoren als neerslag, bedekking bodemoppervlak met sneeuw, dichtheid grasmat, bodemsoort, bodemvochtgehalte en wind worden niet meegenomen. Gepleit wordt daarom om daadwerkelijk de bodemtemperatuur te gaan meten.

De belangrijkste conclusie van de studie is dat bodemtemperatuur een parameter kan zijn waarmee het bemestingsadvies voor de eerste snede verbeterd kan worden. Misschien niet als vervanger van Tsom, maar mogelijk als extra verklarende variabele. 
Geadviseerd wordt om een onderzoek uit te voeren om vast te stellen of met het meten van bodemtemperatuur het bemestingstijdstip voor stikstofkunstmest op gras in het voorjaar beter afgestemd kan worden op de actualiteit voor wat betreft bodem en weer. 


\section{Bijlage 2 Ligging proefvelden}

Ligging percelen

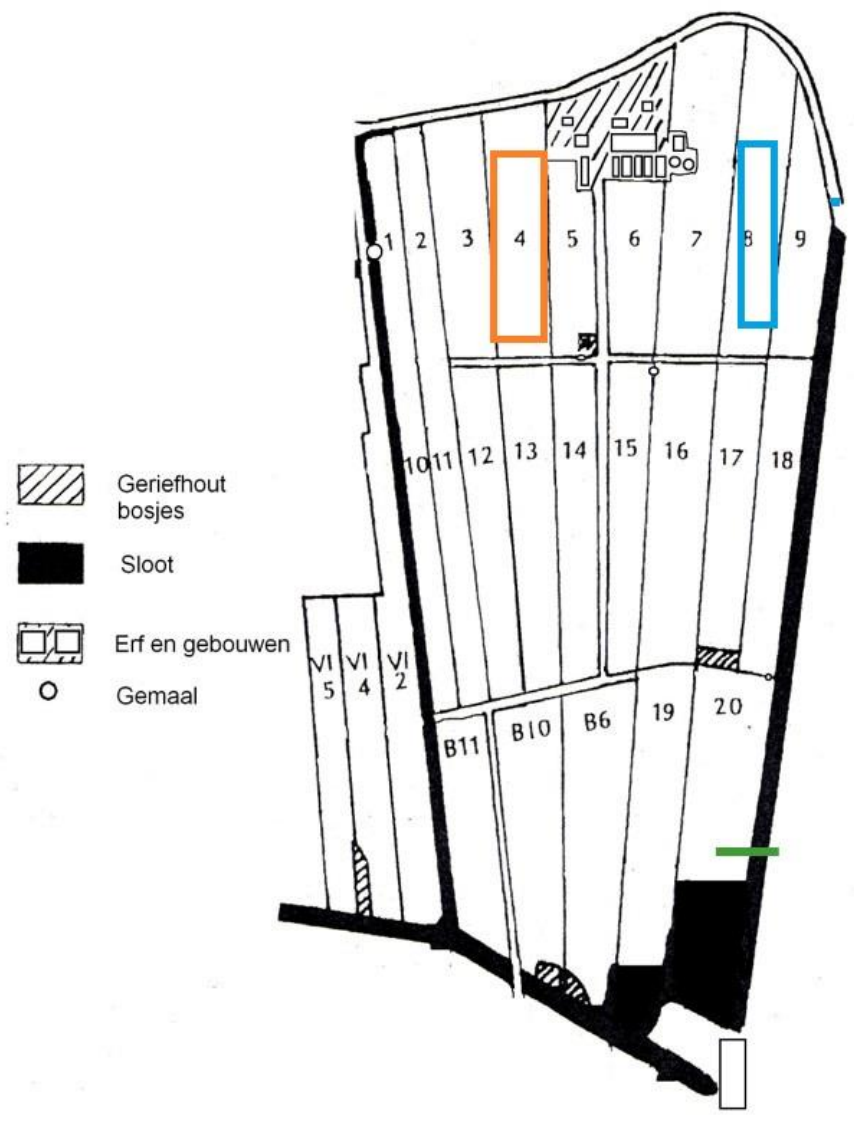

Figuur 1 Ligging proefvelden op KTC Zegveld. Oranje = laag slootpeil, blauw = hoog slootpeil. 


\section{Bijlage 3 Analyse mestmonster}

\begin{tabular}{|c|c|c|c|c|}
\hline Onderzoek & $\begin{array}{l}\text { Onderzoek-fordemr: } \\
4666831004293221 \\
4091 \text { Stenen sllo }\end{array}$ & $\begin{array}{l}\text { Datum monstername: } \\
30-01-2018\end{array}$ & $\begin{array}{l}\text { Datum verslag: } \\
\text { 07-02-2018 }\end{array}$ & $\begin{array}{l}\text { Koplehouder: } \\
\text { CLV de Samenwerking UA, Flore Mulder } \\
\text { Postous 1, 2850 AA HAASTRECHT }\end{array}$ \\
\hline \multirow{12}{*}{$\begin{array}{l}\text { Resultaat } \\
\text { weergegeven in } \\
\text { het product }\end{array}$} & & Eenheld & Resultaat & Landelljk gemiddelde \\
\hline & Droge stof & g DS/kg & 39 & 81 \\
\hline & Ruw as & g RAS/kg & 12 & 19 \\
\hline & Organische stot & g os/kg & 27 & 62 \\
\hline & Stikstof & g N/kg & 2,20 & 4,00 \\
\hline & Cin-ratio & & 6 & \\
\hline & Stkstof-ammonlak & $\mathrm{g} \mathrm{N}-\mathrm{NH}_{9} / \mathrm{kg}$ & 1,1 & 1,8 \\
\hline & Stikstof-organisch & $g \mathrm{~N}$-org/kg & 1,1 & 2,2 \\
\hline & $\begin{array}{l}\text { Fostor } \\
\text { Fostaat }\end{array}$ & $\begin{array}{l}\mathrm{g} P / \mathrm{kg} \\
\mathrm{g} \mathrm{P}_{2} \mathrm{O}_{5} / \mathrm{kg}\end{array}$ & $\begin{array}{l}0,25 \\
0,57 \\
\end{array}$ & 1,50 \\
\hline & $\begin{array}{l}\text { Katum } \\
\text { Kall }\end{array}$ & $\begin{array}{l}\mathrm{g} K / \mathrm{kg} \\
\mathrm{g} \mathrm{K} \mathrm{K}_{2} \mathrm{O} / \mathrm{Kg}\end{array}$ & $\begin{array}{l}3,7 \\
4,5 \\
\end{array}$ & 5,5 \\
\hline & $\begin{array}{l}\text { Magneslum } \\
\text { Magnesia }\end{array}$ & $\begin{array}{l}\mathrm{g} \mathrm{Mg} / \mathrm{kg} \\
\mathrm{g} \mathrm{MgO} / \mathrm{kg}\end{array}$ & $\begin{array}{l}<0,4 \\
<0,7\end{array}$ & 1,2 \\
\hline & $\begin{array}{l}\text { Natrium } \\
\text { Natron }\end{array}$ & $\begin{array}{l}\mathrm{g} \mathrm{Na}_{\mathrm{kg}} \\
\mathrm{g} \mathrm{Na} \mathrm{N}_{2} \mathrm{O} / \mathrm{kg}\end{array}$ & $\begin{array}{l}1,0 \\
1,3\end{array}$ & 0,7 \\
\hline
\end{tabular}

Toellchting Het gemiddelde volumegewicht van deze mestsoort $1005 \mathrm{~kg} / \mathrm{m}^{3}$

De werkingscljers voor deze mestsoort z]n op de achterzl]de vermeld. Indlen er geen

mestsoort is opgegeven, zljn er standaard werkingscljfers afgedrukt. 


\section{Bijlage 4 Temperatuurverloop bodem}

De bodemtemperatuur is voor het perceel met het hoge slootpeil (PR08) voor 2 diepten (10 en $20 \mathrm{~cm}$ beneden maaiveld) weergegeven in Figuur 1.

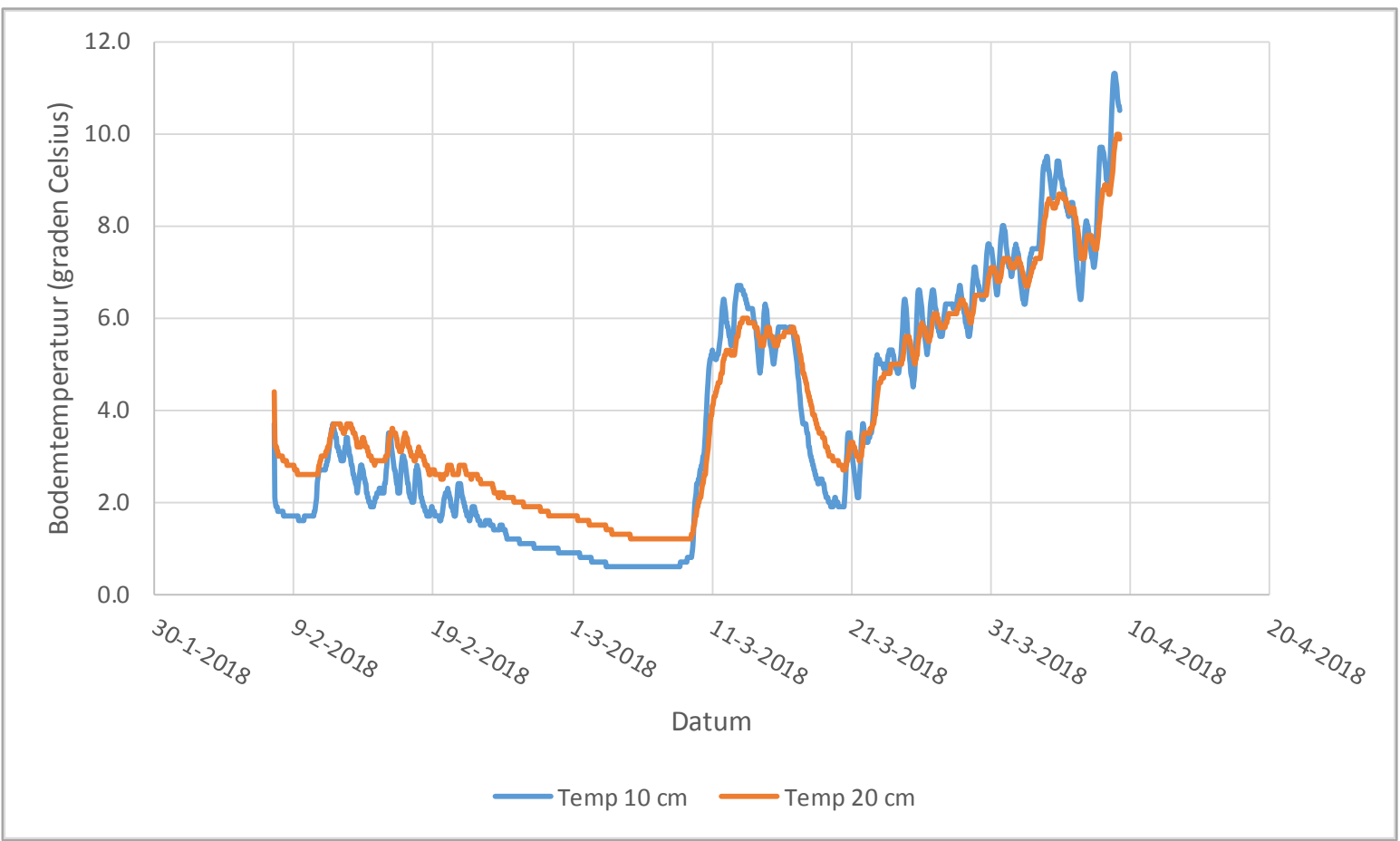

Figuur 1 Temperatuursverloop op 10 en $20 \mathrm{~cm}$ onder maaiveld bij een hoog slootpeil op veengrond.

In deze Figuur is goed te zien dat de temperatuur op $20 \mathrm{~cm}$ diepte de zelfde trend laat zien als die op $10 \mathrm{~cm}$ diepte, maar dat de dag- en nacht verschillen meer worden gedempt. Door de demping is het verloop gelijkmatiger en kan beter geanticipeerd worden op bodemtemperatuur bij het nemen van de beslissing om te strooien. Voor het beslissen om al dan niet te strooien is daarom de bodemtemperatuur op $20 \mathrm{~cm}$ beneden maaiveld als referentie gebruikt. 

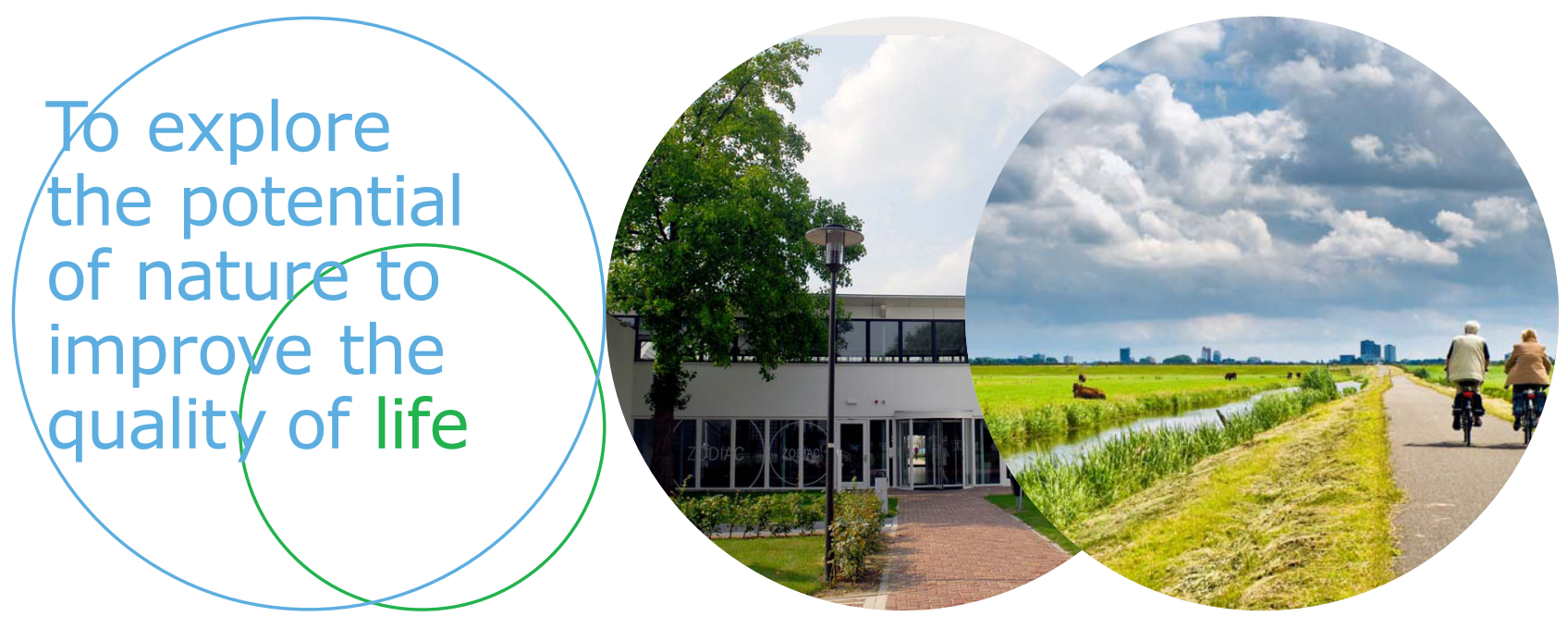

Wageningen Livestock Research Postbus 338

Wageningen Livestock Research ontwikkelt kennis voor een zorgvuldige en $6700 \mathrm{AH}$ Wageningen

T 0317483953

renderende veehouderij, vertaalt deze naar praktijkgerichte oplossingen en innovaties, en zorgt voor doorstroming van deze kennis. Onze wetenschappelijke E info.livestockresearch@wur.nl www.wur.nl/ livestock-research kennis op het gebied van veehouderijsystemen en van voeding, genetica, welzijn en milieu-impact van landbouwhuisdieren integreren we, samen met onze klanten, tot veehouderijconcepten voor de $21 \mathrm{e}$ eeuw.

De missie van Wageningen University \& Research is 'To explore the potential of nature to improve the quality of life'. Binnen Wageningen University \& Research bundelen 9 gespecialiseerde onderzoeksinstituten van Stichting Wageningen Research en Wageningen University hun krachten om bij te dragen aan de oplossing van belangrijke vragen in het domein van gezonde voeding en leefomgeving. Met ongeveer 30 vestigingen, 6.500 medewerkers en 10.000 studenten behoort Wageningen University \& Research wereldwijd tot de aansprekende kennisinstellingen binnen haar domein. De integrale benadering van de vraagstukken en de samenwerking tussen verschillende disciplines vormen het hart van de unieke Wageningen aanpak. 